Final Report to the President on Oil Supply Shortages During 1979

July 1980

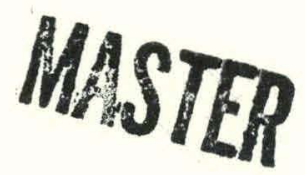

U.S. Department of Energy

Washington, D.C.

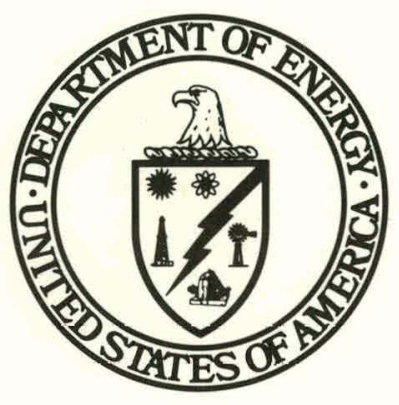




\section{DISCLAIMER}

This report was prepared as an account of work sponsored by an agency of the United States Government. Neither the United States Government nor any agency Thereof, nor any of their employees, makes any warranty, express or implied, or assumes any legal liability or responsibility for the accuracy, completeness, or usefulness of any information, apparatus, product, or process disclosed, or represents that its use would not infringe privately owned rights. Reference herein to any specific commercial product, process, or service by trade name, trademark, manufacturer, or otherwise does not necessarily constitute or imply its endorsement, recommendation, or favoring by the United States Government or any agency thereof. The views and opinions of authors expressed herein do not necessarily state or reflect those of the United States Government or any agency thereof. 


\section{DISCLAIMER}

Portions of this document may be illegible in electronic image products. Images are produced from the best available original document. 
DOE/S-0011

\title{
Final Report to the President on Oil Supply Shortages During 1979
}

\author{
MASTER
}

July 1980

\section{U.S. Department of Energy}

Washington, D.C.
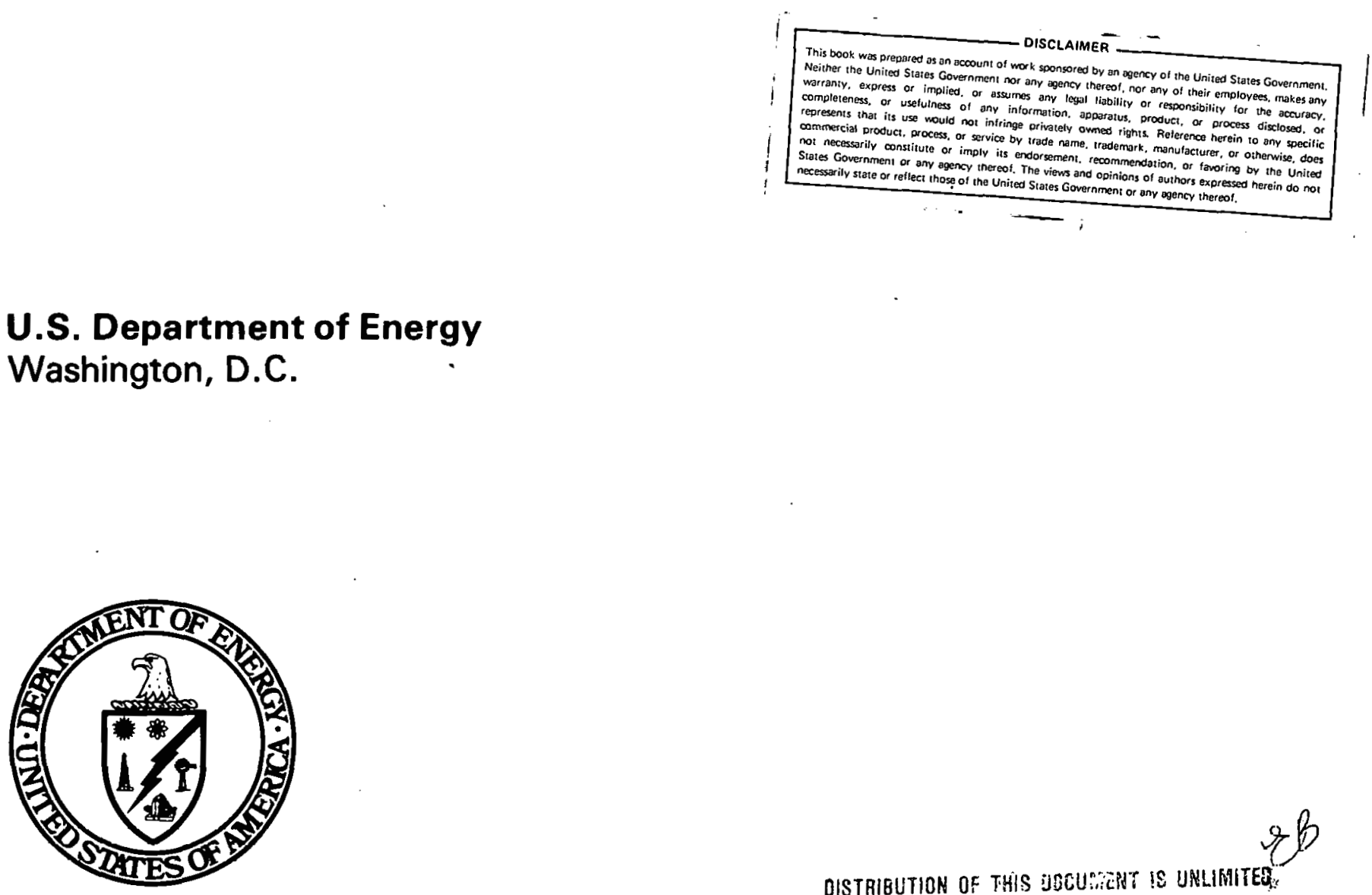

OISTRIBUTION OF THIS jOCU VICN IE UNLIGITES 


\section{TABLE OF CONTENTS}

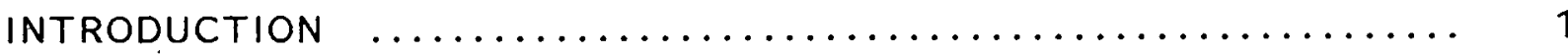

1. VALIDATION OF DATA USED IN THIS REPORT $\ldots \ldots \ldots \ldots \ldots$. 5

11. A NOTE ON THE JULY 24,1979 , REPORT $\ldots \ldots \ldots \ldots \ldots \ldots . . . . . .9$

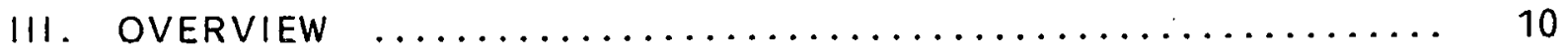

IV. SUMMARY AND DISCUSSION OF FINDINGS $\ldots \ldots \ldots \ldots \ldots \ldots$.

V. SUMMARY OF NATIONAL AGgREGATE DATA $\ldots \ldots \ldots \ldots \ldots . . . . .41$

APPENDIX A: SOURCES OF DATA USED IN THIS REPORT ......... 51

APPENDIX B: COMPARISON OF FINAL DATA WITH PRELIMINARY DATA PRESENTED IN THE JULY 24, 1979, REPORT... 56 


\section{INTRODUCTION}

On May 25, 1979, the President directed the Department of Energy (DOE) and the Department of Justice to investigate the activities of oil companies in connection with the gasoline shortages then being felt. DOE issued a "Report to the President on the Activities of the Oil Companies Affecting Gasoline Supplies" on July 24, 1979 (the Preliminary Report). The Preliminary Report indicated that further work was required before a final report could be issued.

The DOE Final Report examines the causes of the U.S. gasoline supply shortages during the spring and summer of 1979. It is based on an examination of data concerning production and imports of crude oil, and refining, distribution and pricing of petroleum products during 1977, 1978 and 1979. The sources of this data are provided in Appendix A. The analysis in the Final Report generally focuses on the period from May through July 1979, the period when shortages were most evident.

The Final Report is concerned for the most part with aggregated, national statistics. The data in the Final Report provide an accurate picture of the supply situation for the Nation as a whole, but cannot be used to draw reliable conclusions about activities of individual oil companies. The behavior of individual companies during the shortages varied widely. Some companies acted contrary to the general trend; others were in accord with it; still others followed it to an exceptional degree.

During the summer months of 1979, the Secretary and Deputy Secretary of Energy and DOE representatives from the Economic Regulatory Administration (ERA), the Energy Information Administration (EIA) and the Office of General Counsel conducted meetings with major oil companies to question them individually about crude oil and product stock levels, and gasoline and distillate yields. The information provided by the oil companies at these meetings was checked 
against general statistics compiled by EIA. EIA data, largely obtained from the oil companies in response to DOE's mandatory data collection program, was in turn being checked by DOE audit teams examining the records of the 15 largest oil companies and by the independent public accounting firm of Alexander Grant and Company. Both Alexander Grant and Company and the DOE auditors concluded that there was no evidence that the companies studied falsified reports to DOE and that, generally, DOE received valid data from these companies. 1/ The Final Report addresses four subjects mentioned in the Preliminary Report as requiring further study:

(1) The reasons for refiner reluctance to draw down crude oil stocks;

(2) The reasons for reduced refinery yields of gasoline and distillate;

(3) The reasons for substantial quantities of domestic gasoline being sold on the spot market outside the allocation system; and

(4) Whether gasoline or other petroleum was stockpiled by jobbers, distributors or dealers.

With respect to the issue of refiner stocks, DOE found that companies with sufficient supplies of crude oil were refining at capacity and that companies short of crude were actively attempting to secure additional supplies. At the same time, most of the companies questioned were increasing their stocks of petroleum products in response to the uncertainty of future crude oil availability on the world market. '

The reduced yield of gasoline relative to other petroleum products for the period May-July as compared to the same period in 1977 and 1978 was

1/ See generally, "Validation of Data Used in this Report", p. 5.

2/ The Department of Justice, in connection with its investigation of individual company behavior, has collected and examined information concerning custody and ownership of company stocks. EIA is developing a system to collect crude oil ownership data in the future. 
in major part due to increased production of petrochemical feedstocks. Final data indicate that production of middle distillates increased slightly during the same period.

DOE found no general explanation for gasoline moving onto the spot market. Refiners and others explained different volumes of gasoline moving onto the spot market for different reasons. The Office of Special Counsel, the DOE office responsible for auditing the thirty-four largest refiners and for enforcing DOE petroleum regulations with respect to those refiners, is currently examining whether refiners were correctly calculating their allocations.

Finally, DOE has not found it possible to provide a general answer to the question of possible stockpiling by jobbers, distributors or dealers due to the lack of available data. EIA, in conjunction with the Bureau of the Census, has recently instituted a program to collect stock data below the primary supply level. It has not proved feasible to attempt to collect this information retroactively.

Since the beginning of the 1979 shortages DOE has received and investigated a great number of individual allegations and reports concerning asserted manipulative actions at various levels in the oil industry. These include alleged nocturnal dumping of gasoline into the Mississippi River, storage of petroleum products in concealed facilities in western desert regions, and, particularly, a number of reports that gasoline storage tanks at various locations in the United States were overflowing at a time when consumers were having difficulty purchasing gasoline. DOE promptly considered or investigated, as appropriate, all such charges and found them generally to be unsubstantiated. For example, in the case of one highly publicized report that storage tanks in northern Virginia were mysteriously full while retail gasoline suppliers were short in the Washington metropolitan area, DOE examined a 
substantial number of pipeline and tank owner primary records and found that no unusual or excessive storage existed at the time and place alleged. DOE also received reports of oil tankers lying off the coast with the charge or implication that petroleum was being held off the market. At DOE's request the U.S. Coast Guard investigated these reports and none were substantiated.

The Final Report does not address questions of enforcement of DOE administered regulations or laws, or other laws affecting oil company behavior. ERA's Office of Special Counsel and Office of Enforcement continue to investlgate violations of DOE regulations and to bring enforcement proceedings against violators. The Department of Justice, the Executive Branch agency with primary responsibility for administering the antitrust laws, will include a study of possible antitrust violations in its report to the President. 
I. VALIDATION OF DATA USED IN THIS REPORT

This report is based upon data collected by the Energy Information Administration (EIA) of the Department of Energy (DOE). Much of DOE's data is obtained from oil companies in response to DOE's mandatory data collection program. 3 /

In the course of the Office of Special Counsel's audit of selected refiners' compliance in 1979 with DOE allocation regulations, Special Counsel on-site audit teams also performed a verification audit of the companies' 1979 reporting on their production and inventories. In all cases, the volumes reported by the companies were reconciled with the companies' internal records and ledgers with only nominal discrepancies.

To further assess the accuracy of EIA data, DOE retained Alexander Grant and Company, an independent public accounting firm that does not work-for any major oil company, to examine the reliability of inventory data refiners submit to DOE and to review the quality of EIA methods for processing and reporting inventory data submitted by refiners.

Alexander Grant and Company evaluated the inventory accounting systems of five major refiners: Chevron U.S.A., Exxon U.S.A., Gulf, Shell, and Texaco. Together these refiners represent less than 15 percent of all refineries that report inventory data to DOE, but represent approximately 35 percent of domestic oil refinery capacity. The study focused on the preparation of eleven DOE reporting forms: six monthly reports and five weekly reports.

3/ ElA collects information in over 20 different data systems at various levels throughout the petroleum industry. This permits crosschecking of data for purposes of corroboration. Company responses to standard questionnaires from EIA are required to be certified by the companies. This information is subject to audit and criminal penalties of $\$ 10,000$, five years imprisonment, or both are provided for knowingly making a false statement in response to EIA questionnaires. 18 U.S.C. $\$ 1001$. ElA data is also compared with information from other sources, including the Internal Revenue Service, State tax and petroleum production offices, independent firms, distributors and jobbers. 
As part of this study Alexander Grant and Company conducted an incidental validation of a sample of crude and product inventory data both by review of original source documentation and physical inspection of inventories. This sample validation effort indicated that data reported to DOE was accurate except for nominal clerical errors.

In a press briefing accompanying DOE's release of the Alexander Grant and Company report, the Grant and Company partner responsible for the study stated that the firm had found no evidence that the five companies studied falsified any reports to DOE and concluded that, generally, DOE received valid data from the companies studied. The report concluded that the five companies appeared capable of providing reasonably accurate inventory data, although the quality of data varied among refiners and differed for the weekly and monthly reports. The report also pointed out the existence of conditions within the reporting companies which, from time to time, might produce inaccurate results without additional controls. The conditions possibly contributing to some measure of inaccuracy in company monthly reports to DOE included the following:

(1) Lack of rechecking after reports are first prepared;

(2) Misunderstanding of reporting requirements and report definitions;

(3) The need to use a manual procedure to supplement a computer program for certain inventory data;

(4) Insufficient management participation in data collection and report preparation; and

(5) Lack of formal reconciliation between custody basis data requested by DOE and internal ownership basis data.

The report was critical of EIA for failure to integrate the numerous systems EIA inherited from its predecessor and concluded that: 
"ElA does not have sufficient in-house data processing staff to support present systems or develop new systems. Too much knowledge of the present system resides with contract personnel."

In response to this report and as part of its comprehensive data quality improvement program, EIA has several important efforts underway to improve the quality of DOE data on petroleum stocks and supplies. These include the following:

o in May of 1979, EIA established the National Energy Information System Office to develop an integrated, accessible, comprehensive body of energy information. This office is responsible for coordinating DOE automation to meet the needs of government and private users, including an examination of processing methods in preparing DOE's weekly and monthly statistical publications.

The National Energy Information System Office is also responsible for investigating further several issues raised in the Alexander Grant and Company report, including a detailed review of refiner inventory data requirements.

- In January 1980, ElA published a report entitled "Verification of Petroleum Industry Information." This report responded to a request from Senate and House Appropriations Committees to investigate the possibility of certifying domestic petroleum supplies. The report also addressed issues of data to be collected, from whom, and how the data should be validated.

- EIA is developing a data system to monitor major refiners' stocks of crude oil and other feedstocks on an equity basis. Initial implementation is expected in the fall of 1980 .

- EIA is in the process of consolidating four different crude oil data systems that collect similar or duplicative data for statistical, regulatory or international reporting purposes. 
- As part of DOE's responsibilities under the Emergency Energy Conservation Act of 1979, ElA conducted a study of commercial and industrial storage of fuel. The study used existing sources of information to evaluate stock levels of fuel oil and gasoline. The study was sent to Congress on May 2, 1980 . Furthermore, in August 1979, EIA and the Bureau of the Census began collecting secondary stock information on middle distillate and residual fuel oil. Collection of secondary stock information on motor gasoline began on January 1, 1980.

- ElA's ongoing data validation program involves both a preventive and a remedial approach to improving the quality of energy information. Preventative validation takes the form of a critical evaluation of proposals for new or modified energy information systems. The remedial approach involves detailed validation of operational energy information systems. These studies assess, in quantitative terms, the accuracy and meaningfulness of existing systems, and recommend improvements. Petroleum product marketing systems are included in EIA's 1980-81 validation plans: 


\section{A NOTE ON THE JULY 24, 1979 REPORT}

As noted in the Introduction, a Preliminary Report to the President on the activities of oil companies affecting gasoline supplies during 1979 was issued by the Department of Energy on July 24, 1979. The Preliminary Report was based on an analysis of preliminary data for the period February-May, 1979, and presented comparisons with the same periods in 1978 and 1977.

The Final Report is based on final data, and aggregates this data over the January-April and May-June periods in order to focus clearly on the period when gasoline supply shortages were most evident. The period examined in the Preliminary Report, therefore, is included in the periods examined in the Final Report but on a basis that is not strictly comparable. To facilitate direct comparisons between the final data used in the Final Report and the preliminary data used in the Preliminary Report, Appendix B presents updated versions of some tables that appeared in the Preliminary Report. 


\section{OVERVIEW}

During May-July of 1979, U.S. refiners supplied about $650 \mathrm{mb} / \mathrm{d}$ (8.5\%) less gasoline to the distribution system than they had supplied during the same period in the previous year. Total oil supplied by refiners was about $560 \mathrm{mb} / \mathrm{d}$ (3.1\%) less during May-July, 1979, and the total available for supply including stocks that were available but not used was $790 \mathrm{mb} / \mathrm{d}$ ( $3.9 \%$ ) less, relative to the same period in 1978.

The primary factors underlying this overall reduction in availability and supply to consumers were the levels of stockpiles at the beginning of 1979, the level of imports during the first half of the year, and inventory management.

Either a higher level of imports (as in 1977) or a higher level of stocks (as in 1978) would have been necessary in 1979 to match the availability of oil in these earlier years. In fact, stocks available for drawdown were $40-70 \%$ less than they had been at the beginning of 1978, and imports during the first half of the year were only moderately higher than in 1978. (It should be recognized that 1978 was a year of abnormally high opening stock levels and abnormally low imports.) The 1979 supply problem was compounded by the fact that Alaskan production had levelled off between 1978 and 1979, and production in the lower 48 states continued the decline that had begun in 1971. Finally, on the demand side, 1979 consumption would have been 2-3\% higher than 1978 if there had been no shortage. This much additional supply, relative to 1978, would have been required to avoid a shortage. 
Two factors limited the availability of imports. First, world crude supplies were reduced by 2 million b/d in the first quarter of 1979 due to the Iranian disruption. Second, there is some evidence that U.S. oil imports fell short of the level that would be expected if world supplies had been allocated strictly in accordance with the pattern of world demand, especially during the second quarter of 1979. Of the several factors that may have contributed to this, one of the most important was an accelerated shift of control of internationally traded oil in 1979 from major oil companies, which were the traditional source of foreign supply for the U.S., to other international companies, independents, traders, and, increasingly, to state-owned oil companies and national governments. It may also be that high spot market prices and the efforts of DOE to discourage bidding those prices up further dissuaded U.S. refiners from acquiring crude on the spot market. Finally, U.S. government purchases through the Strategic Petroleum Reserve Program were rapidly phased out during the spring and summer of 1979. While purchases by other governments for strategic stockpiles were also phased out during this period, foreign government purchases of crude for refining and supply to consumers were increasing.

Since increased imports did not compensate for lower levels of stocks at the beginning of 1979 , the other way refiners could have supplied more oil would have been to draw down inventories as low as possible without jeopardizing flow in the system. Although total stocks available for drawdown on April 1 were 40-70\% lower in 1979 than in 1978 and gasoline stocks were $30-40 \%$ lower, there was still a margin between current stock levels and minimum operating levels, and further drawdown would have been possible. Instead, stocks were generally 
built up, particularly in the case of gasoline during June and July. By the end of July, total stocks were rising towards the lower boundary of the normal range, and gasoline stocks were in the middle of the normal range.

The result of this combination of factors was a shortage of gasoline available to the consumer: the difference between supply and demand at prevailing prices. Based on DOE estimates of what demand would have been had supply not been restricted during May-July of 1979, the gasoline shortage was between 500 and $700 \mathrm{mb} / \mathrm{d}(7-10 \%$ of actual supply). Of the principal petroleum products, gasoline was especially affected for three reasons. First, the shortage occurred during the peak season for gasoline demand, while it was the off-season for residual and distillate fuel oil demand (the other two most important petroleum products); second, refiners built up gasoline stocks more than stocks of other products; and third, refiners traded off a degree of gasoline production for increased production of petrochemical feedstocks. During the May-July period, refiners' yield of middle distillates did not differ significantly from the yield during the same period in the two previous years. This is an indication that refiners did not sacrifice gasoline production during the shortage period in order to meet the President's goal of 240 million barrels of distillates in primary storage by October 1979.

The most plausible explanation for refiners' building up gasoline stocks was refiners' uncertainty about continued access to crude oil. When Iranian production resumed in March of 1979, that resumption did not restore the world oil market to the condition which had prevailed in the period before the Iranian disruption. Even though world production in the spring and summer of 1979 had returned to 
predisruption levels, a worldwide surge in stock building and normal demand increases (demand growth remained positive outside the U.S. during and after the disruption) led to an extremely tight market. There were also dramatic changes in the pattern of world oil distribution. The international oil majors lost large contract volumes from Iran and elsewhere and were forced to cut third party sales. Their refiner customers in turn were obliged to seek alternative supply sources. Direct marketing by the producer nations to national governments, national oil companies, and on the spot market was increasing. All of these developments made the continuity of crude oil supply to U.S. refiners much more uncertain than before November 1978, even after predisruption production levels were resumed.

For those refiners who were constrained by DOE price controls, or Council on Wage and Price Stability guidelines, stockpiling gasoline would not have helped to increase profits. This is because the revenues and profits allowed by DOE and CWPS are a function of crude oil and other costs at the time the gasoline is refined, not at the time the gasoline is sold. 4 /

Most refiners actually charged less, even during the shortage, than the price allowed under DOE's price controls. The most plausible explanation for this is that the Council on Wage and. Price Stability's (CWPS) voluntary price guidelines were more constraining

4/ This report does not consider whether individual refiners conspired to withhold gasoline in order to drive up prices. As noted at page 4, the Department of Justice will consider possible antitrust violations by the oil companies in its report to the President. In addition, DOE's Office of the Special Counsel is conducting fifteen audits of the allocation practices of some of the largest oil companies." 
than DOE price regulations, and these refiners were attempting to comply with the CWPS guidelines. $\underline{5}$ /

The gasoline price increases that took place between January and September of 1979 largely reflect crude oll cosl increases, incrcased energy costs in refining, and increased costs and margins at the retail level. Much of this retail cost increase appears to have been incurred and banked prior to January of 1979. Additionally, 3.7 cents per gallon of the price increase is attributed to refiner and reseller's overhead cost increases, labor, transportation, passthrough of previously banked costs, and/or illegal (under DOE regulations) overcharging by refiners. 6 /

5/ A recent Council on Wage and Price Stability Staff Report, "Petroleum Prices and the Price Standard," February 25, 1980, indicates that less than 0.4 cents/gallon of the increase in refiners' margins during the period October 1978-October 1979 was attributable to noncompliance with the guidelines.

6/ The Department of Energy is investigating the possibility of pricing and/or allocation violations by refiners, jobbers and resellers at all levels of the petroleum industry. Some of these investigations have resulted in Notices of Probable Violation being issued against alleged violators; other investigations are continuing and may result in additional enforcement proceedings. 


\section{SUMMARY AND DISCUSSION OF FINDINGS}

\section{A. SUMMARY OF FINDINGS}

1. Stockpile levels at the beginning of 1979, imports during the first half of the year, and inventory management were primarily responsible for the oil supply shortage in the spring and summer of 1979.

2. There was a 3.1\% reduction in oil supply in May-July of 1979 relative to the same period in 1978, and a $0.2 \%$ reduction relative to 1977 . Relative to 1978, the key factor was reduced use of stocks. Relative to 1977 , the key factor was reduced imports. Relative to demand, which had grown by $1.5-2.5 \%$ since 1978, the supply shortfall, in May-July 1979 was 5-6\%.

3. The reduction in available oil between 1979 and previous years was even greater than the reduction in supply.

4. Domestic production of crude oil declined between May-July of 1978 and the same period in 1979. This was consistent with the long-term trend.

5. Free-world oil production dropped by about 2 million $b / d$ during the first quarter of 1979 as a result of the loss of Iranian production. Production returned to pre-disruption levels by the middle of 1979 .

6. The U.S. share of free-world oil supply dropped by $2 \%$ in the second quarter of 1979 compared to the 1977-78 average. However, the U.S. share during this period of 1979 was actually $2 \%$ greater than the 1975-76 average.

7. Gasoline supplied to consumers during May-July 1979 was $8.5 \%$ less than in the same period in 1978, and 7-9\% less than the amount that would have been consumed in this period if there had been no supply restriction. Compared to 1978, reduced gasoline production during this period in 1979 accounted for $36 \%$ of the supply reduction, and reduced use of stocks accounted for $64 \%$ of the supply reduction. 
8. Refiners could have made more gasoline available during May-July of 1979 without reducing stocks below minimum operating levels.

Refiners' conservative stock management practices were probably due to the disruption in international crude oil markets at the time and the increased uncertainty regarding crude supply in the second half of the year.

9. The yield of gasoline relative to other petroleum products went down in May-July of 1979 as compared to the same period in 1977 and 1978. Most of the compensating increase was in production of petrochemical feedstocks. The yield of middle distillates increased very little, indicating that there was no significant tradeoff of gasoline production for heating oil production during the period of the gasoline shortage.

10. Refiners who were bound by DOE price controls or who were complying with CWPS guidelines could not have increased allowable revenues by delaying the sale of gasoline. The CWPS program was generally more constraining than DOE's during 1979.

11. Virtually all of the gasoline price increases that took place between January and August 1979 were based on cost increases. 


\section{B. DISCUSSION OF FINDINGS}

The basic findings of this analysis are presented below. Section $V$ of this report presents in more detail the data on which these findings are based. Overall Oil Supply and Availability

1. Stockpile levels at the beginning of 1979, imports during the first half of the year, and inventory management were primarily responsible for the oil supply shortage in the spring and summer of 1979.

The upper portion of Figure 1 shows the relationship between U.S. oil consumption and new supply of crude and products. If The components of new supply, production and imports, are shown in the bottom part of Figure 1 . During the second and third quarters of most years, stockpiles typically are built up as consumption dips below the level of hew supply. During the first and fourth quarters, when consumption peaks, the level of supply stays below the level of demand, and stocks are drawn down. Nineteen seventy-seven was typical in following this pattern, although the degree of stock buildup in 1977 was unusually high.

The pattern in 1978 was atypical because the unusually high stocks at the beginning of the year allowed the use of stocks to substitute, to some degree, for imports. Import levels during 1978, especially during the second quarter, were much lower than they would have been if the stock level at the beginning of the year had not been so far above normal. By the middle of 1978, stocks

7/ New supply differs from supply to consumers in that the former does not include the use of stocks. Supply to consumers is new supply plus or minus the use of stocks (depending on whether they are being drawn down or built up). 
Figure 1. U.S. Oil Consumption, New Supply, and Components of New Supply (Including NGL)

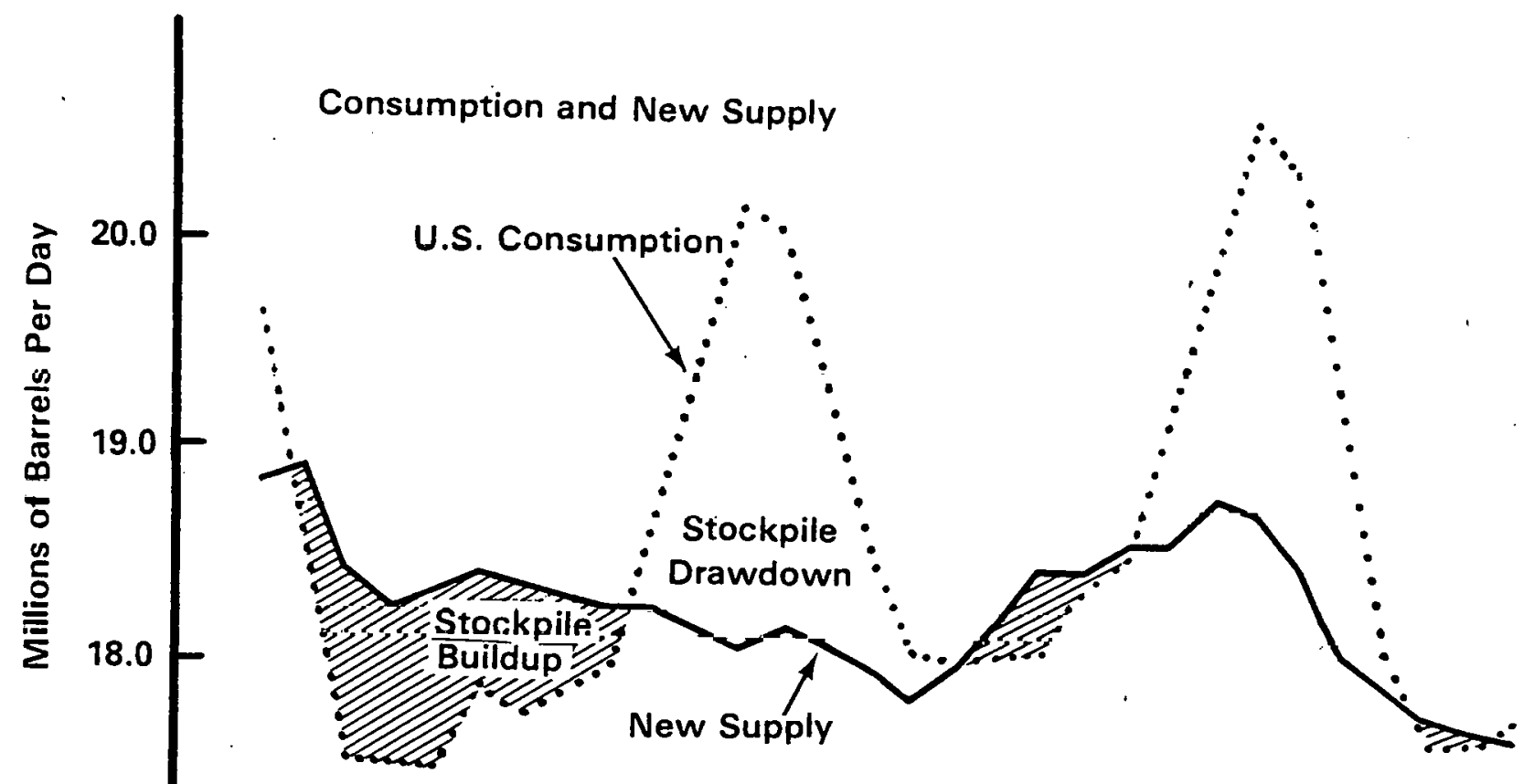

Components of New Supply

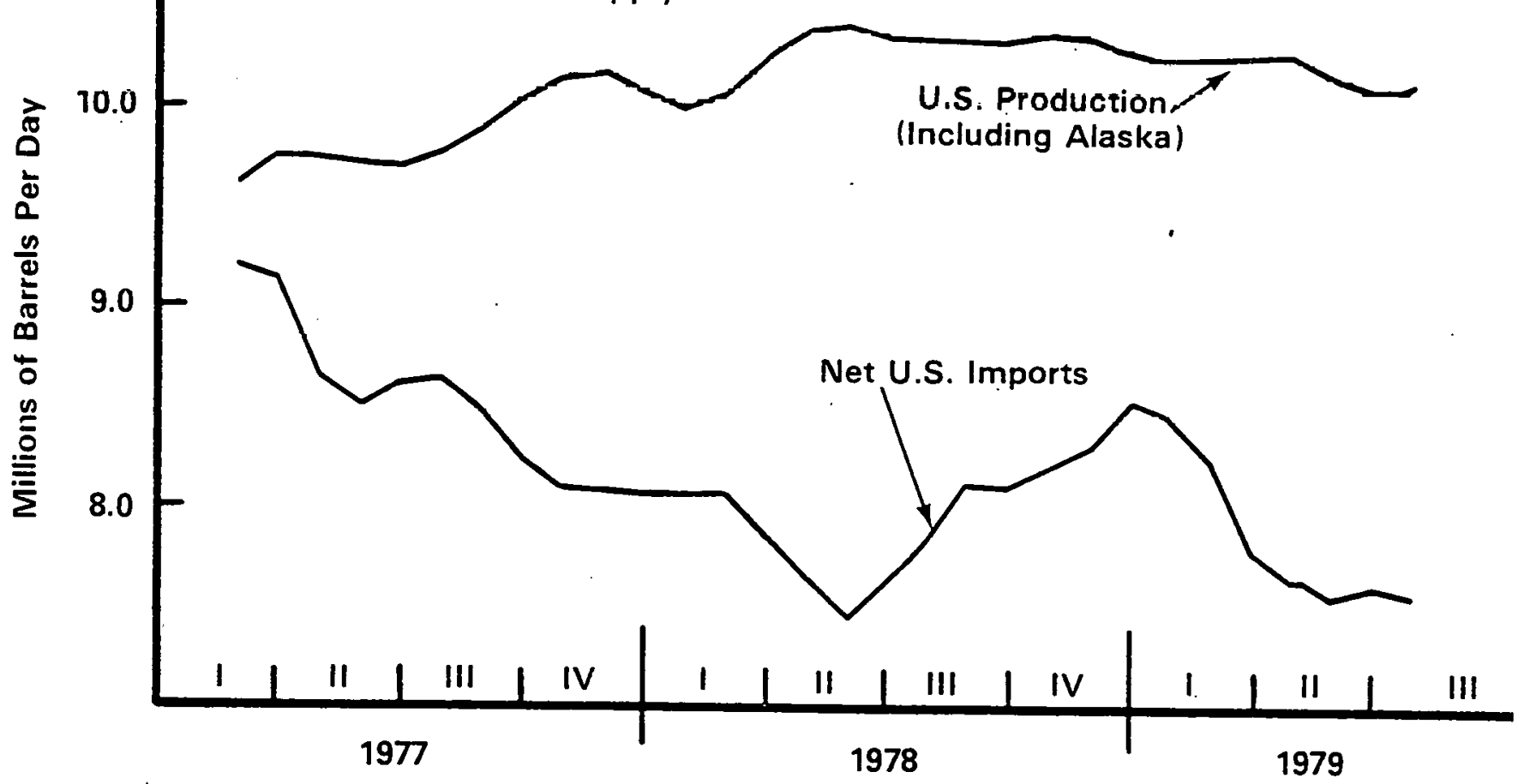

Note: Each point plotted in this figure represents an average over the preceding three months. 
had been reduced to the normal range and were still within that normal range at the time of the Iranian disruption at the end of 1978.

Entering 1979 with a normal level of stocks, refiners also needed a normal level of imports in order to meet demand. The necessary import level for the first half of 1979 was substantially greater than the actual import level during the first half of 1978 which, as noted above, was abnormally low. Instead, imports during the first and second quarters of 1979 closely matched the levels of the previous year. Refiners were able to meet demand during the first quarter of 1979 (which was $2 \%$ greater than in the first quarter of 1978) through very large stock drawdowns, and by the end of the first quarter stocks were well below the normal range.

During the second quarter of 1979, imports continued to fall, and domestic production also fell off somewhat. Only a sharp surge in imports during the second quarter would have allowed new supplies to keep up with demand.

The degree to which inventory management affected the shortage at the consumer level is discussed in pages 32-35.

2. There was a $3.1 \%$ reduction in oil supply - / in May-July of 1979 relative to the same period in 1978 , and a $0.2 \%$ reduction relative to 1977 . Relative to 1978 , the key factor was reduced imports. Relative to demand, which had grown by $1.5-2.5 \%$ since 1978, the supply shortfall in May-July 1979 was 5-6\%.

Table 1 shows the difference between 1979 and the two previous years for the three basic elements of oil supply. The table shows daily averages for the January-April period and the May-July period. Positive numbers indicate that 1979 supply exceeded that of the earlier year, while negative numbers (in parentheses) indicate that there was a reduction in 1979. See Table 7, page 41 , for the data from which Table 1 is derived.

8/ Supply is defined as the sum of crude and natural gas liquids production, net imports of crude, feedstock and products, and use of stockpiles, which can either add to supply (stock drawdown), or subtract from supply (stock buildup). 
Table 1 shows that, relative to 1978, there was a small supply increase during the first four months of 1979 , but that a substantial reduction in supply occurred during May-July.

Compared to 1978 , reduced use of stocks was the most important factor underlying the 1979 reduction in supply whereas imports were actually higher in 1979. Taken by itself, this comparison is misleading since it fails to recognize that stocks in 1978 were abnormally high and imports were abnormally low. The comparison of 1979 to 1977, a year in which imports were very high and stocks about normal, implies that the cause of the 1979 shortage was low imports. A full accounting of the problem in 1979 must recognize that the combination of stock levels at the beginning of the year and import levels during the first half of the year was responsible. Demand can be met by relying primarily on high levels of inventories at the beginning of the year as in 1978, or by relying on high levels of imports as in 1977. In 1979, neither of these alternatives was available.

To determine the amount by which supply fell short of demand, it is necessary to estimate what demand would have been if there had been no shortage. Figure 4 on p.28 indicates that oil consumption in the U.S. was running $1.5-2.5 \%$ higher than the previous year during the fourth quarter of 1978 and the first quarter of 1979. Assuming this growth rate would have continued had there been no shortage, the shortfall during May-July 1979 is equal to $5-6 \%$, the sum of the supply shortfall relative to 1978 and the demand growth. It should be recognized that this represents an average shortfall measure for all products, including some whose supply was actually in surplus, e.g., residual fuel oil, and some whose shortfall was greater than the average for all products, e.g., gasoline. 
Table 1

Difference Between 1979 and Previous Years

For Elements of Overall Oil Supply*

(Thousands of Barrels Per Day)

January-April Average

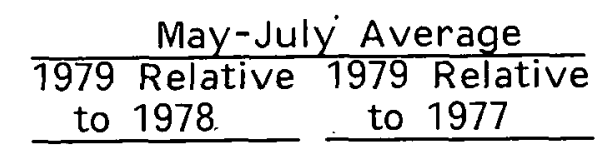

Domestic Production 1979 Relative 1979 Relative

to 1978

to 1977

90

560

(270)

390

of Crude Oil and

Natural Gas Liquids

Net Imports of Crude

150

$(1,080)$

220

$(920)$

Oil, Feedstock, and

Products**

Use of Stocks

(Crude, Feedstock,

1,160

(490)

410

and Products)*****

Other**** 10

(240)

(20)

80

TOTAL SUPPLY

60

400

(560)

(crude oil and. product)

Note: Parentheses indicate reductions in 1979 relative to the earlier year.

* Positive numbers indicate that 1979 exceeded the earlier year for this element of supply. Numbers in a parentheses are negative numbers, and indicate that 1979 saw a reduction relative to the earlier year. See Table 7, page 41 for the actual values of each element of supply in each period in each year.

** Excluding Strategic Petroleum Reserve.

*** In comparing stock use, drawdowns are considered as positive numbers (additions to supply), while buildups are considered as negative numbers (subtractions from supply). See Table 9, page 45, for monthly stock levels in 1977, 1978, and 1979.

**** Includes refinery gain, crude oil losses, crude oil unaccounted for, and other hydrocarbons and hydrogen refinery input. 
3. The reduction in available oil $9 /$ between 1979 and previous years was even greater than the reduction in supply.

To measure the difference in the amount of oil available (crude and product) between two years, it is necessary to adjust the difference in supply by the difference in the amount remaining in stock at the end of the period under consideration. This adjustment is shown in Table 2 which indicates that the reduction in available crude oil between May-July of 1979 and the same period of 1978 averaged $790 \mathrm{mb} / \mathrm{d}$, and $830 \mathrm{mb} / \mathrm{d}$ relative to 1977 .

Table 2

Difference Between 1979 and Earlier Years

in the Availability of 0il\%

(Thousands of Barrels per Day)

$\frac{\text { January-April }}{1979 \text { Relative } 1979 \text { Relative }} \quad \frac{\text { May-July }}{1979 \text { Relative 1979 }}$

\begin{tabular}{|c|c|c|c|}
\hline $\begin{array}{c}1979 \text { Relative } \\
\text { to } 1978\end{array}$ & $\begin{aligned} & 1979 \text { Relative } \\
& \text { to } 1977\end{aligned}$ & $\begin{array}{c}1979 \text { Relative } \\
\text { to } 1978\end{array}$ & $\begin{array}{c}1979 \text { Relativ } \\
\text { to } 1977\end{array}$ \\
\hline 60 & 400 & $(560)$ & (40) \\
\hline
\end{tabular}

Total Supply

Difference (crude

60

(560)

oil and product)

Adjustment for

Leve1 1 it

Difference in

Available 0il

110

(790)

* To compare availability between two years, the difference in supply in the two years is adjusted to account for the difference in the amount that remained in stockpiles at the end of the period in each year.

t: This is calculated by subtracting the closing stock level in the earlier year from the closing stock level in 1979 and dividing by the number of days in the period (120 for January-April, and 92 for May-July).

9/ Available oil is defined as the amount of crude and product supplied plus the additional amount that could have been supplied if stocks had been drawn down to minimum operating levels. 
4. Domestic production of crude oil declined between May-July of 1978 and the same period in 1979.

This was consistent with the long-term trend.

As shown in Table 1, domestic production of crude oil and natural gas liquids declined by $267 \mathrm{mb} / \mathrm{d}$ between May-July of 1978 and the same period in 1979. Table 3 shows the components of this production for 1977, 1978 and 1979. The total reduction between 1978 and 1979 consisted of a $394 \mathrm{mb} / \mathrm{d}$ reduction in crude production in the lower-48 states, offset in part by increased production of natural gas liquids and Alaskan crude.

Table 3

Components of Domestic Production of Crude $0 i 1$ and Natural Gas Liquids (May-July Average)

(Thousands of Barrels Per Day)

$\begin{array}{crrr}\text { Crude 0il } & \underline{1977} & \underline{1978} & \underline{1979} \\ \text { Lower 48 } & 7,820 & 7,510 & 7,120 \\ \text { Alaska } & 270 & 1,290 & 1,330 \\ \text { Natural Gas Liquids } & 1,620 & 1,560 & 1,640 \\ \text { TOTAL } & \frac{1,510}{9,710} & 10,360 & 10,090\end{array}$

Two explanations have been suggested for this substantial decline in lower-48 production. The first is that in the aggregate these production reservoirs have passed their peak producing years, so that their maximum efficient production level is now declining steadily. The second suggested explanation is that production was deliberately reduced below maximum efficient levels, for purposes of economic gain.

Examination of the trend of lower 48 production since 1971 suggests that the reduction was attributable to natural causes. Figure 2 shows crude oil production in the lower 48 states during 1977-79. The trend line in the figure 
Figure 2. Crude Oil Production in Lower 48 States

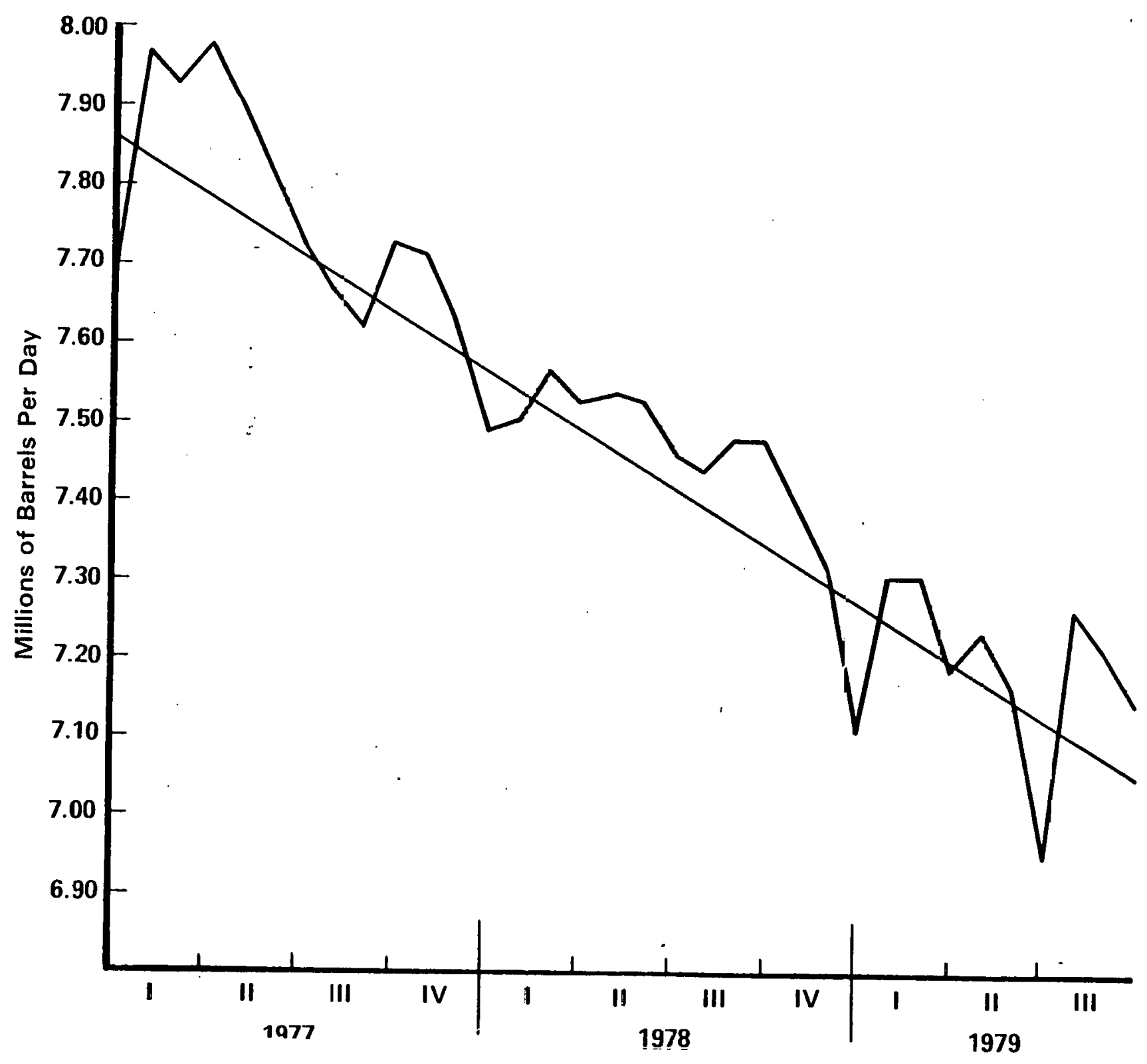


was fit against monthly production levels going back to January 1973. 10/ The trend line shows that production in the lower 48 was declining at the rate of about $300 \mathrm{mb} / \mathrm{d}$ per year. The decline that took place between 1978 and 1979 is consistent with this long-term trend, and probably resulted mostly from the natural decline in the maximum production capacity of these mature reservoirs. While this analysis does not disprove the theory that crude oil production was deliberately. suppressed, the analysis implies that any suppression of production that may have taken place did not involve volumes that were significant in the context of the 1979 supply shortage. The actual production levels during May-July 1979 were about $50 \mathrm{mb} / \mathrm{d}$ less than the predicted levels following the long-term trend.

5. Free-world oil production dropped by about 2 millivi' $\mathrm{b} / \mathrm{d}$ during the first quarter of 1979 as a result of the loss of Iranian production. Production returned to predisruption levels by the middle of 1979.

Figure 3 shows rolling 3-month average crude oil production levels for the entire free world, i.e., the noncommunist countries, and for the entire free world excluding Iran. Iranian production is represented by the space between the two lines. The figure shows that between the 3-month period ending November 1978 and the 3-month period ending March 1979, total free-world crude oil production dropped by about 2 million $b / d$. Production in the free world excluding Iran rose by 1.8 million b/d during this time, and Iranian production dropped by 3.8 million $\mathrm{b} / \mathrm{d}$. (These figures show less drastic

10/ The correlation coefficient was .96. The correlation did not increase when seasonality was taken into account. 
Figure 3. Components of Total Free Worlc Crude Oil

Production (Iran verses Rest of 'World)y

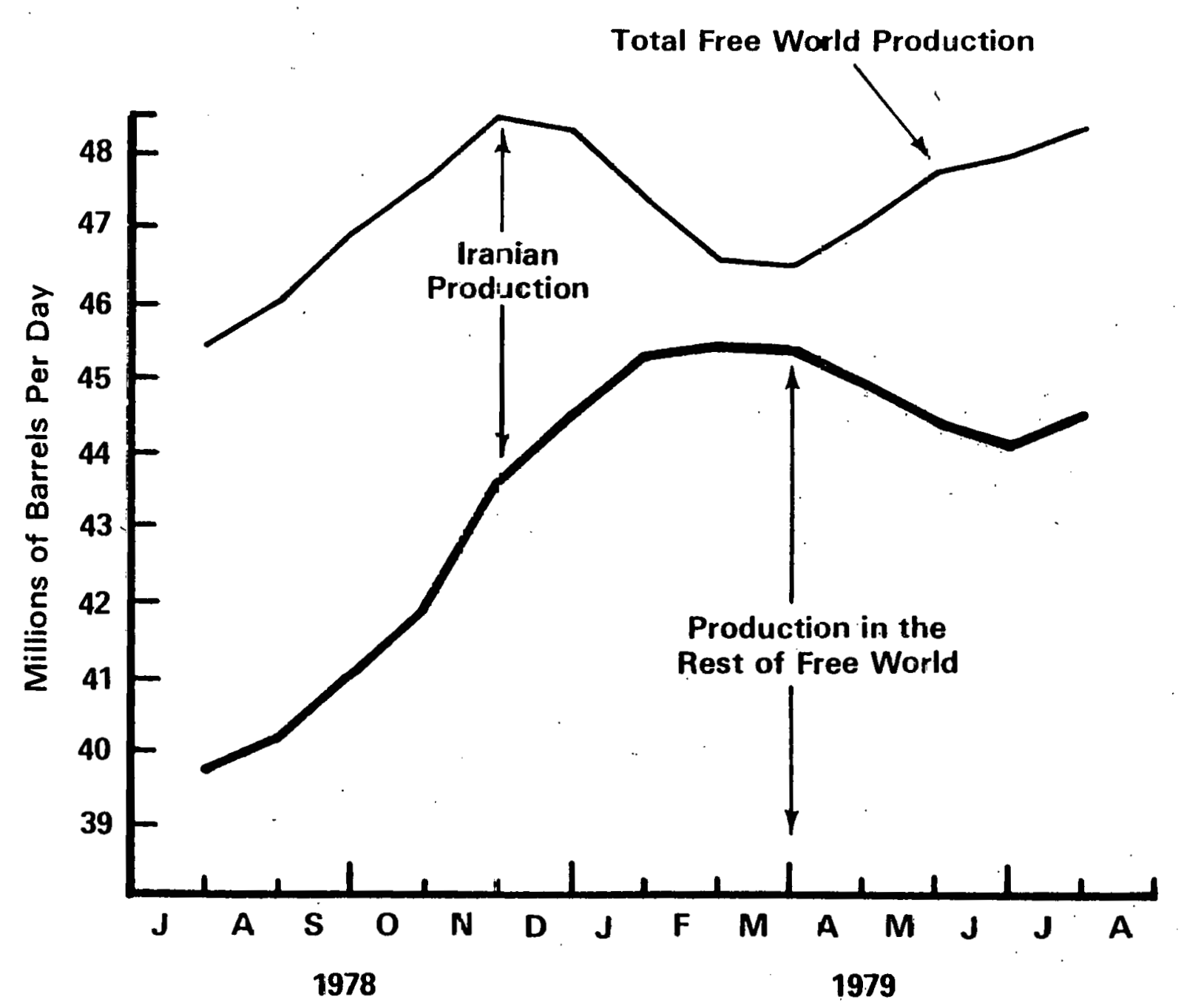

1/ Each point in the figure represents the average production level over the preceding three months: 
swings than other published reports because they are 3-month averages.) Production increases in the rest of the world did not, therefore, entirely compensate for the loss of Iranian production.

6. The U.S. share of free-world oil supply dropped by $2 \%$ in the second quarter of 1979 compared to the 1977-78 average. However, the U.S. share during this period of 1979 was actually $2 \%$ greater than the 1975-76 average.

Figure 4 shows new free-world oil supply $11 /$ over the 1977-79 period, the non-U.S. share of that supply, and the U.S. share.12/

The dotted lines in the middle and lower portions of Figure 4 provide an arbitrary benchmark for measuring changes in the relative supply shares of the U.S. and the rest of the world. The dotted line in the middle portion of the figure represents $64 \%$ of the total world new supply shown in the upper portion of the figure. The dotted line in the lower portion represents $36 \%$ of total world new supply. This division of supply was the average division for 1977-78.

It is apparent that the U.S. share dropped sharply in the second quarter of 1979 relative to the average over 1977-78. The 1977-78 average U.S. share was about 36\%, while the share for May-July 1979 was $34.1 \%$. The difference is equal to about 1 million barrels per day of actual supply during the second quarter of 1979.

11/ New free-world oil supply is free-world production plus net imports from Communist countries.

12/ New U.S. supply is equal to domestic production plus net imports. It differs from supply to consumers because the latter is the former plus or minus the use of stockpiles. The relationship is illustrated in Figure 1 on page 18. 
Figure 4. New World Oil Supply, Non-U.S, Supply, and U.S. Supply

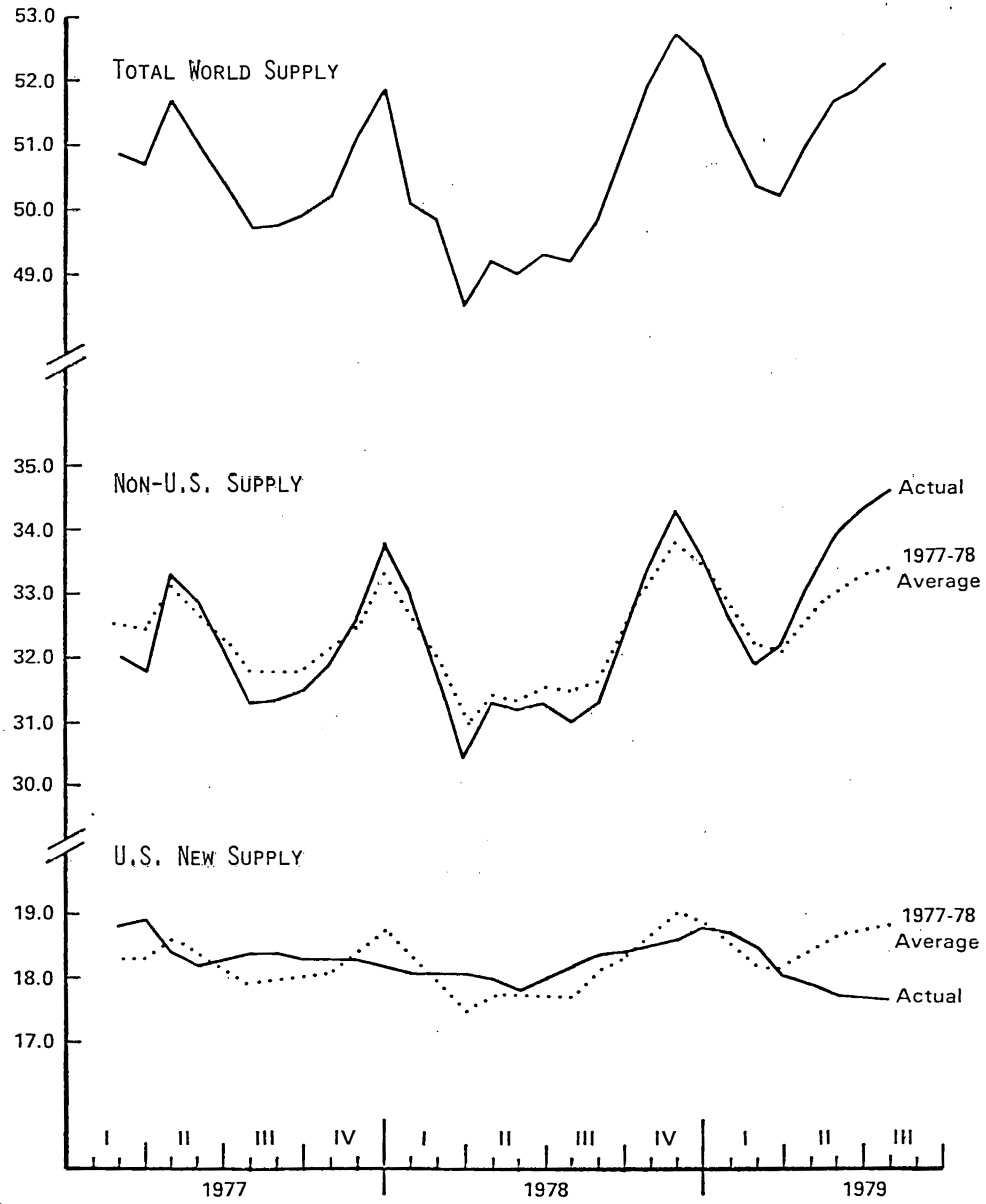

Note: Each point plotted in this figure represents an average over the preceding three months. 
During 1975-76 (not shown in Figure 4) the U.S. share of new world supply averaged about $32.5 \%$. The question raised by Figure 4 is why the U.S. share dropped back towards the pre-1977 level in the second quarter of 1979. 13/ One answer may be that the U.S. share of world demand dropped commensurately, where demand is understood not as what was actually supplied to consumers, but what consumers would have purchased if there had been no supply restriction. A relative demand decline probably did occur in $1979, \underline{14 /}$ and accounts for some part of the reduction in U.S. share in 1979. However, it is also true that U.S. consumers received less than they were willing to purchase during May-July of 1979 while consumers in the rest of the world did not experience comparable shortages although gasoline shortages were reported in the U.K. and distillate shortages in Sweden. The drop in U.S. supply share at the beginning of 1979 was therefore apparently greater than the drop in demand share (where demand is defined as what would have been consumed if there had been no shortage) and is not altogether explained by underlying trends in demand. See Figure 5, page 42, for a comparison of consumption trends in the U.S. and the other IEA nations during 1979.

The conclusion here is that some portion of the 1 million $b / d$ which the U.S. lost relative to its share of supply during the two preceding years was lost because of a decline in demand, and the remaining portion was lost because the U.S. did not fare as well as other nations in gaining access to world oil

13/ Changes in domestic production would not account for changes in the U.S. share, so long as the world oil market operates freely and competitively. The effect of domestic production changes is to alter the mix of imports and domestic production in meeting domestic demand, and to change the total world supply available. But the division of that supply among nations should be in proportion to consumer demand.

14/ Industrial production in Japan, West Germany, France, the U.K, and Italy grew $3.8 \%$ during the first half of 1979, whereas U.S. industrial production growth during the same period was $1.8 \%$. 
during the second quarter of 1979. Several factors have been suggested as contributing to this pattern of distribution of world production:

- Trade on the world market shifted somewhat away from the major oil companies towards direct sales by producing nations to consuming nation governments. This shift put the U.S. in a weaker access position than previously, because the major oil companies had been the traditional means of access to the world market. Also, the U.S. government did not become a purchaser of crude for supply to the Nation's refineries, whereas many other, governments did.

- Government and private stocks may have been built up more rapidly in the rest of the world than in the U.S.

- Crude oil was traded increasingly on the spot market, and for a time DOE sought to discourage U.S. companies from making spot market transactions in an effort to restrain the upward bidding of spot market prices. It is evident that these intentions were frustrated to the extent that other nations continued to purchase oil on the spot market.

- The major oil companies may have given higher allocations of their available supply to affiliates operating in non-price-controlled markets, or sold some supply in foreign spot markets. Although preliminary investigation has revealed no evidence of this, DOE has asked the International Energy Agency to thoroughly examine this question in an upcoming study of oil allocations by the international companies during 1979. 
7. Gasoline supplied to consumers during May-July 1979 was $8.5 \%$ less than in the same period in 1978 , and $7-9 \%$ less than the amount that would have been consumed in MayJuly 1979 if there had been no supply restriction. Compared to 1978, reduced gasoline production during this period in 1979 accounted for $36 \%$ of the supply reduction, and reduced use of stocks accounted for $64 \%$ of the supply reduction.

Table 4 shows the elements of gasoline supply for the May-July period in 1977, 1978 and 1979. The 1979 supply was $660 \mathrm{mb} / \mathrm{d}$ (8.5\%) less than the 1978 supply. The difference in use of stocks between the two years accounted for $420 \mathrm{mb} / \mathrm{d}$ of the reduction (see Finding 8 , page 32), while reduced refinery gasoline production accounted for $240 \mathrm{mb} / \mathrm{d}$ in 1979 (see Finding 9, page 35).

Table 4

Elcments of Gasoline Supply

May-July Average

(Thousands of Barrels Per Day)

\begin{tabular}{lrrr} 
& \multicolumn{1}{c}{1977} & $\underline{1978}$ & $\underline{1979}$ \\
Production & 7,110 & 7,180 & 6,940 \\
Net Imports & 230 & 200 & 210 \\
Use of Stocks & 10 & $\underline{350}$ & -70 \\
\multicolumn{1}{c}{ TOTAL SUPPLY } & 7,350 & 7,740 & 7,080 \\
April 30 Stock Level* & 259 & 249 & 235 \\
July 31 Stock Level* & 258 & 216 & 242
\end{tabular}

* Millions of barrels.

DOE estimates that gasoline demand would have been $7600-7770 \mathrm{mb} / \mathrm{d}$ during May-July 1979 if there had been no supply restriction. The estimate is based on the actual consumption level for the same period in 1978, and includes 
adjustments for income growth, price increases, fleet size growth, and increased fuel efficiency between 1978 and 1979. 15 /

Actual demand in May-July 1979 was affected also by a number of psychological and convenience factors that are not taken into account in this estimate. However, these factors (reduced hours of operation, long lines, concern about being stranded, and a spirit of conservation) were themselves the result of the shortage. If supply had not been restricted, $7600-7770 \mathrm{mb} / \mathrm{d}$ is probably a reasonable estimate of the amount that would actually have been consumed. The difference between this DOE demand estimate and the amount actually supplied is $520-690 \mathrm{mb} / \mathrm{d}$. This much additional supply was needed during May-July 1979 to avoid the shortage. This is $6.8-8.8 \%$ of what demand would have been in the absence of a shortage.

8. Refiners could have made more gasoline available during May-July 1979 without reducing stocks below the minimum operating levels. Refiners' conservative stock management practices were probably due to the turmoil in international crude oil markets at the time and the increased uncertainty regarding crude supply in the second half of the year.

Gasoline stocks at the end of July 1979 were 242 million barrels which was in the middle of the normal range. The July 31, 1978 level was 216 million barrels. The estimated minimum operating level for the gasoline supply system is 200-210 million barrels. 16/ Table 11, page 46, shows monthly stock levels.

15/ The low end of the range of estimates reflects a price elasticity of demand of -.2 , and an income elasticity of .50 . The high end assumes a price elasticity of -.1 and an income elasticity of .75 . These values are representative of the empirical evidence on price and income elasticity of demand for gasoline.

16/ This amount is needed to keep tanks and pipelines full to the degree required to avoid loss of flow in the system. See discussion on page 44. 
It would therefore have been possible to draw an additional $280 \mathrm{mb} / \mathrm{d}$ from stocks for supply during May-July 1979 without drawing stocks below the July 31, 1978 level. An additional $350-460 \mathrm{mb} / \mathrm{d}$, relative to the actual amount supplied, might have been supplied without causing a breakdown in the system, although the probability of doing so becomes quite high as the 200 million barrel level is approached. $17 /$

Refiners' reluctance to use these stocks appears to have resulted from conditions in the world oil market following the resumption of Iranian production in March. Pre-disruption market conditions were not restored along with the resumption of Iranian production. There were two reasons for this. First, demand was much higher after the disruption than it had been before, because in addition to the normal growth in demand (demand growth remained strong outside the U.S.), the disruption created a worldwide drive to build stockpiles. What had been a slack market prior to the disruption became an extremely tight one following the disruption, even though worldwide production was resumed at levels higher than pre-disruption levels. Soaring spot market prices were a result.

The second change was the effort by some producing nations to effect a shift from contract sales, which guarantee a refiner fixed volumes at predictable intervals well into the future, to one-time-only spot market transactions. During the slack markets of 1976, 1977 and 1978, availability of supply in the spot market had not generally been a problem and prices were usually below those in the contract market. In order to take advantage of the lower spot market prices, most refiners were therefore covering a portion of their requirements through spot purchase even before the producing nations cut back on contract

17/ It is significant that stocks of gasoline were drawn down steadily after July 31, 1979, and added about $190 \mathrm{mb} / \mathrm{d}$ to supply through mid-November. This would not have been possible had stocks been drawn down to minimum operating levels at the end of July. 
sales during and after the disruption. The difference after the disruption was that the reduced contract coverage was now accompanied by spiraling spot market prices and uncertainties as to whether crude would regularly be available in the spot market.

One factor which may have contributed to the stockpiling of gasoline and other products that began in June 1979 'was the action of the international oil companies in invoking force majeure and pro-rating deliveries to refiners with which the internationals had crude supply contracts. There is some evidence that this did not become widespread until well into the spring of 1979, when many producing countries began to reduce liftings allowed by the major oil companies in order to increase sales directly to other governments or in the spot market. It may be that until this occurred, U.S. refiners had not generally been concerned about future supply.

When future crude supplies are uncertain, one possible reaction is for refiners to increase gasoline stockpiles because of their concern with providing continuous service in their established market areas. In the long run, a refiner that maintains reduced but continuous deliveries will be in a better position than a competitor that maintains deliveries at high levels for a few months but then is forced to cut back drastically.

In anticipation of potential shortages of gasoline, DOE updated the base period for gasoline allocations in February 1979, so that the allocation program would more closely reflect recent market patterns (44 F.R. 11202, Feb. 28, 1979). In that notice, DOE also expressed concern that refiners would draw down gasoline stocks precipitously as soon as the first impacts of a shortage were felt, and urged refiners to keep stocks high enough to meet expected demand during the 1979 summer driving season. In the aggregate, refiners drew down stocks at a moderate pace in March, April and May. However, as gasoline lines and 
spot shortages began to occur in May and June, refiners reduced the amount of gasoline stocks available for supply. In the aggregate, there was a net buildup of gasoline stocks during June and July. During this period, DOE repeatedly criticized refiners for overcautious stock management practices and urged more liberal use of stocks to relieve the supply situation.

9. The yield of gasoline relative to other products went down in May-July of 1979 as compared to the same period in 1977 and 1978. Most of the compensating increase was in production of petrochemical feedstocks. The yield of middle distillates increased very little, indicating that there was no significant tradeoff of gasoline production for heating oil production during the period of acute gasoline shortages.

Table 5 shows the difference between the actual May-July production levels of various refined products and the production levels that would have resulted if the average yield fractions for May-July of 1977 and 1978 had been achieved. If the yield in the two earlier years had been maintained, gasoline, aviation fuel, and residual fuel oil production would have been $270 \mathrm{mb} / \mathrm{d}$ greater, and production of petrochemicals, kerosene, middle distillates, and other products would have been $270 \mathrm{mb} / \mathrm{d}$ less. Gasoline suffered the largest reduction in 1979 $(=170 \mathrm{mb} / \mathrm{d})$, and petrochemicals realized the largest gains $(+160 \mathrm{mb} / \mathrm{d})$. Middle distillate production increased by only $20 \mathrm{mb} / \mathrm{d}$, indicating that there was no significant shift towards middle distillates relative to previous years. This indicates that although DOE's 240 million barrel target for middle distillate stocks in October of $1979 \underline{18 /}$ had already been announced, gasoline production

18/ On April 7, 1979, DOE announced a $240 \mathrm{mb} / \mathrm{d}$ stockpile target for distilTates for October, to assure adequate heating oil supplies for the winter. Each of the large refiners was informed of his individual target, and progress towards these individual targets was monitored by DOE. The target was reached during the third week of October. 
was not traded off for middle distillate production during the period when gasoline shortages were most pronounced.

For refiners who were bound by the DOE price controls but not bound by (or not adhering to) the CWPS guidelines, the shift towards petrochemicals may have been motivated by profit considerations, since petrochemicals prices were not controlled by DOE, and since the petrochemicals industry is willing to pay more for feedstock (demand is less elastic) than the gasoline consumer. It may also be significant that some of the large oil companies also own petrochemical companies. Capacity expansions and production increases in the petrochemicals industry have averaged $10-20 \%$ during the last few years, and it appears that some refiners may have decided to meet the growing requirements of petrochemicals customers including their own affiliates at the expense of gasoline production. The DOE allocation program would not have prohibited this because it only allocated gasoline actually produced but left refiners free to choose what mix of products to produce.

Table 5

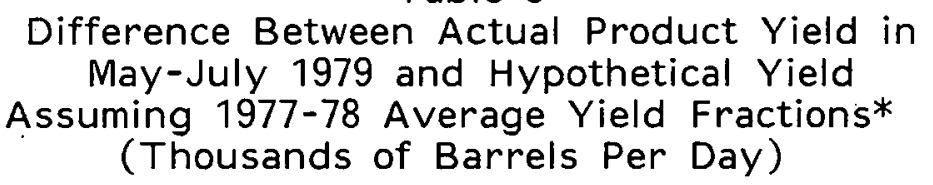

Motor Gasoline

Aviation Fuels

Petrochemicals

$+160$

Kerosene

$+40$

Middle Distillates

$+20$

Residual Fuel Oil

$-80$

Other

$+55$

TOTAL DIFFERENCE

* See Table 12, p. 48, for the actual production levels and yield fractions. 
10. Refiners who were bound by DOE price controls or CWPS guidelines could not have increased allowable revenues by delaying the sale of gasoline. The CWPS program was generally more constraining than DOE's during 1979.

The principle underlying DOE's price control program is that price and revenue increases may not exceed cost increases. Since delaying the sale of gasoline can do nothing to increase the cost of producing it, stockpiling cannot increase the allowable amount of revenues recovered. Allowable revenues are a function of costs at the time the product is produced, not at the time when it is sold.

Examination of data showing refiners' banked costs (costs recognized as recoverable by DOE but not actually passed through in prices) shows that most refiners were not charging the maximum prices allowed by DOE during much of 1979. Two explanations have been suggested. First, it is argued that competitive market forces were preventing refiners from charging the maximum prices allowed by DOE. While this may well have been the case for some refiners, especially prior to May, stockpiling would have been a counterproductive strategy for an individual refiner to pursue in this situation, since the existence of competitive pricing forces means that competitors have additional volumes that they are willing to market at prevailing market prices. Under these circumstances, a stockpiler would have no effect on market prices. He would merely lose market share. The strategy would, of course, make sense if enough refiners in a given market area were to withhold supply cooperatively. Investigation of such questions is primarily the responsibility of the Department of Justice, which is preparing its own report on the gasoline shortages.

The second explanation for the fact that refiners apparently did not recover all the costs allowed by DOE during much of 1979 is that the voluntary 
price guidelines monitored by the Council on Wage and Price Stability (CWPS)

allowed less cost passthrough than the DOE price controls. 19/ However, wherever CWPS was the binding constraint on revenues, the same conclusion holds as where DOE controls were the binding constraint: stockpiling does nothing to loosen the constraint and allow increased revenues, because delayed sale of a product (stockpiling) does nothing to increase the cost of producing the product. In conclusion, stockpiling would not have been an effective means of increasing revenues so long as market prices were being restrained either by DOE, CWPS, or competitive market forces, unless refiners were prepared to violate the CWPS guidelines, the DOE regulations and/or the antitrust laws. Of course, a refiner who incorrectly anticipated the termination of the DOE and CWPS programs in time to make stockpiling pay would have had an incentive to stockpile. Since the price controls did remain in effect, however, such a strategy would not have paid off.

Another possible effect of the CWPS program may have been to encourage stockpiling of gasoline during June 1979 in order to avoid violating the guidelines. Refiners whose costs and revenues in April and May left them in danger of exceeding the guidelines for the second quarter would have had an incentive to postpone sale of some gasoline until after June 30 in order to stay within the limit. The CWPS program did not, however, provide any incentive to build

19/ For example, CWPS required that the extra $10 \%$ volumetric tilt of crude oil costs towards gasoline allowed by DOE be offset by a tilt away from crude cost passthrough in other products. DOE could not have required this, without reimposing price controls on other products. It appears that the tight supply conditions in markets for non-controlled petroleum products allowed refiners to passthrough $100 \%$ volumetrically on those products. Since CWPS limited total passthrough to $100 \%$, the extra volumetric $10 \%$ allowed on gasoline by DOE could not be recovered and, as a result, banked costs for gasoline under the DOE price control programs increased steadily during 1979. For many refiners, CWPS, rather than DOE, was controlling the price of gasoline. 
stocks in July, when the largest buildup actually took place, because CWPS compliance is measured by measuring the average margin over the entire quarter (July, August and September).

11. Virtually all of the gasoline price increase that took place between January and September 1979 was based on cost increase.

Table 6 shows a breakdown of the components of the leaded regular gasoline price increase between January and September 1979. The crude oil cost component is equal to $110 \%$ of refiners' average crude oil acquisition cost, reflecting the higher value of crude in gasoline than in heavier products. (See footnote 21, page 49.) The third row shows the increase for a category combining refiners' and resellers' overhead, labor, transportation, passthrough of costs incurred prior to 1979 but not passed along in prices at that time, and such illegal overcharges as actually occurred.

The fourth row shows a similar composite category for retail operations. It is believed that retailers had very substantial banked costs prior to the shortages in May which allowed them to raise prices by substantially more than their current cost increases once the shortages developed. On August 1, 1979, the price regulations governing retailers were changed to allow retailers a fixed margin regardless of the amount of costs banked. The fourth row also includes whatever revenues were collected by retailers in excess of those allowed by DOE. Table 13 on page 50 shows the actual cost components from which Table 6 is derived. 
Table 6

Components of Leaded Regular Gasoline

Price Increase - January-September 1979

(Cents Per Gallon)

$\begin{array}{lcc}\text { Crude Oil Cost } & 18.5 & (62.0 \%) \\ \text { Refinery Energy Cost } & 1.2 & (4.0 \%) \\ \text { Refiner/Reseller Margin* } & 3.7 & (12.4 \%) \\ \text { Retail Margin** } & 5.7 & (19.1 \%) \\ \text { Retail Tax } & -.7 & (2.3 \%) \\ \quad & 29.8 & (100.0 \%)\end{array}$

* Includes increases in costs of overhead, labor, transportation and purchased gasoline, as well as passthrough of previously banked costs and such illegal overcharges as may have occurred.

** Includes increased costs of overhead, passthrough of previously banked costs, and such illegal overcharges as may have occurred. 
V. SUMMARY OF NATIONAL AGGREGATE DATA

A. Total Petroleum Supply and Demand

Table 7 shows the total amount of petroleum supplied during the January-April and May-July periods in 1977, 1978 and 1979.

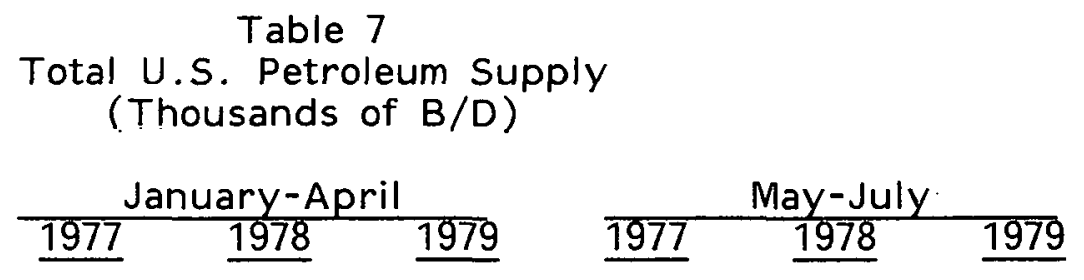

Domestic Production of

Crude Oil and

National Gas Liquids $\quad 9,680 \quad 10,150 \quad 10,240 \quad 9,710 \quad 10,360 \quad 10,090$

Net Imports of Crude *

Feedstocks and

Products

$9,020 \quad 7,790 \quad 7,940 \quad 8,610 \quad 7,480 \quad 7,700$

Use of Crude, Feedstock, and Product Stocks*

\begin{tabular}{rrrrrrr}
-80 & 1,270 & 1,080 & $-1,280$ & -380 & -870 \\
\hline 530 & $\frac{280}{19,150}$ & $\frac{290}{19,490}$ & $\frac{480}{19,550}$ & $\frac{580}{17,520}$ & $\frac{560}{18,040}$ & 17,400
\end{tabular}

* Excluding Strategic Petroleum Reserve.

** Includes refinery gain, crude oil losses, crude oil unaccounted for, and other hydrocarbons and hydrogen refinery input.

Figure 5 shows the percent change in total oil consumption relative to the previous year for the U.S. and the other IEA nations plus France. $\frac{20 / \text { Relative }}{2}$

20/ The figure plots rolling three-month averages, where each point represents the average over the preceding three months. 
to 1978 , U.S. consumption growth was positive until May 1979. European and Japanese growth moved sharply ahead of the U.S. beginning in December 1978 and remained positive throughout the Iranian supply disruption and the resulting crude oil price increases.

Figure 5. Percent Change in Total Oil Consumption Relative to the Previous Year, U.S. and Other IEA Nations Plus France (Based on Rolling 3-Month Averages)

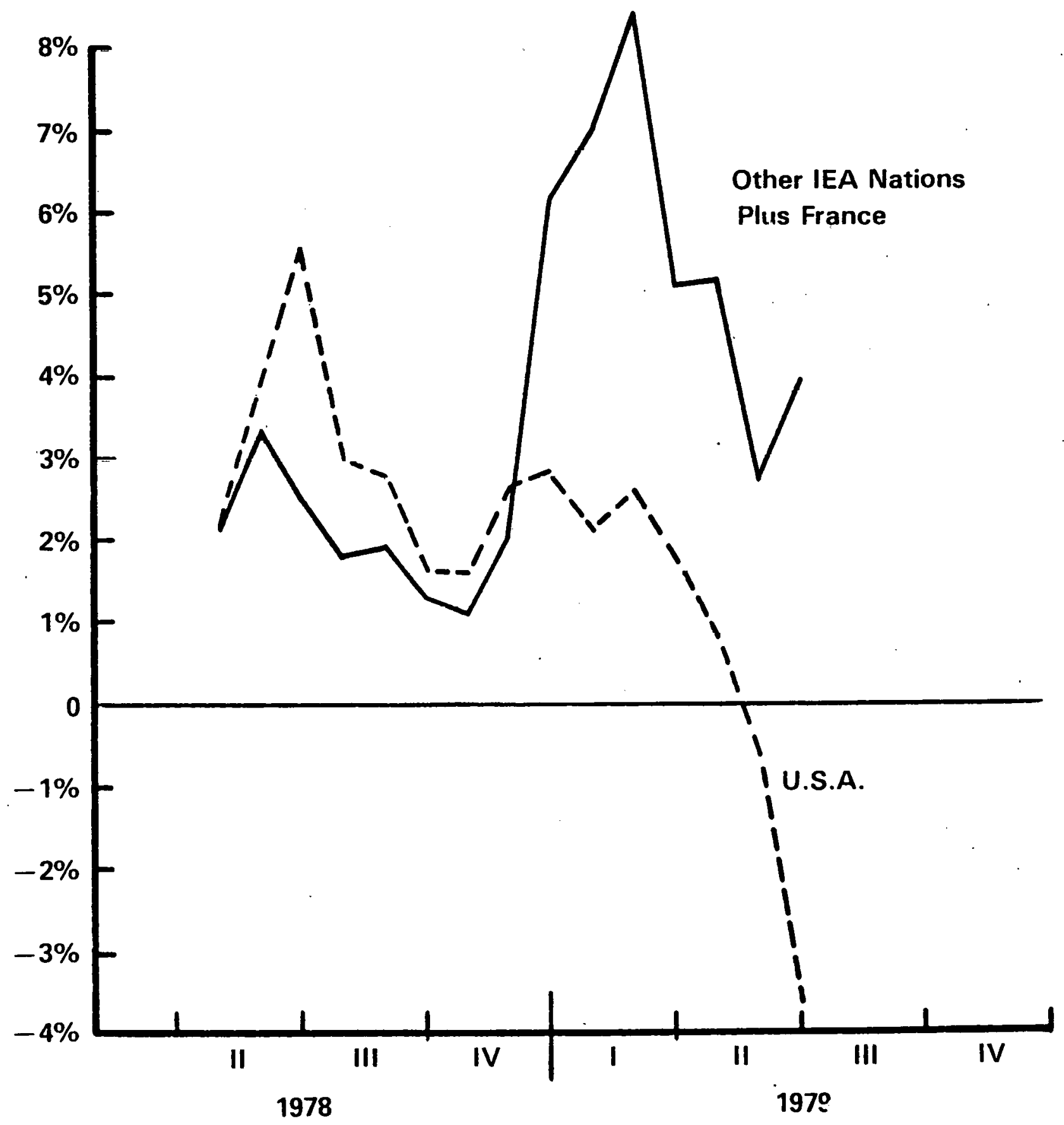




\section{B. Elements of Gasoline Supply}

Table 8 shows the elements of gasoline supply for 1977, 1978 and 1979. Supply is equal to refinery production plus imports plus (or minus) stock changes, which can either add to (stock drawdown) or subtract from (stock buildup) supply. For the May-July period, the peak period of gasoline shortages in 1979, supply was $657 \mathrm{mb} / \mathrm{d}$ less than in 1978 .

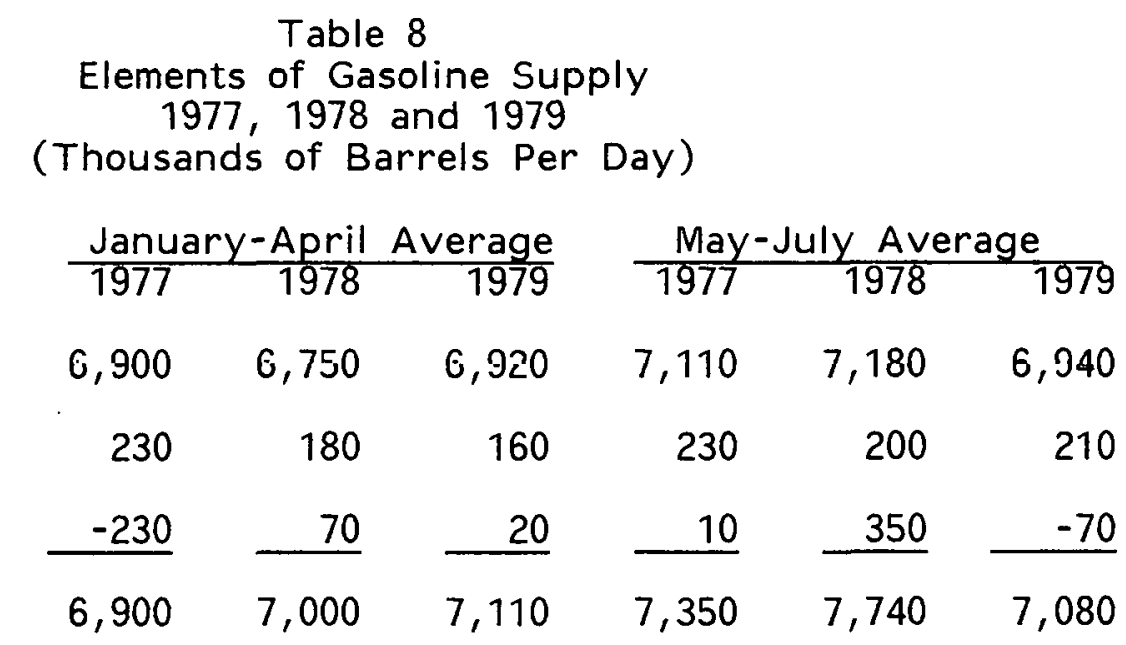

* Positive numbers indicate stock drawdown. Negative numbers indicate stock buildup.

** Numbers may not add to TOTAL due to independent rounding. 


\section{Total Stocks}

Table 9 shows beginning of month stocks for all oil (crude oil, feedstock, and products) exclusive of stocks held in the U.S. Strategic Petroleum Reserve.

If an assumption is made regarding the minimum operating level for stocks, then the amount available for drawdown can be calculated. The minimum operating level is the amount of oil necessary to keep the supply system operational, to keep tanks and pipelines full enough to allow continuous flow. In actuality, there is a minimum operating region rather than a single level. Towards the upper end of the region, interruptions appear only intermittently and in isolated areas. Towards the lower end of the region, the supply system begins to break down altogether. The center point of the range is a function of the technology of the system and to a lesser extent, the level of demand.

While there is considerable uncertainty associated with estimates of the minimum operating level, a reasonable estimate for stocks of all oils lies in the range of 950-1,030 million barrels. For gasoline, the range is probably from 200-210 million barrels.

Assuming this range for the minimum operating level, the amount of stock available for supply at any point in time can be calculated as the difference between the actual level and the minimum. Table 10 summarizes the percent differences between 1978 and 1979 for January 1 and April 1. The low end of the range reflects the low end of the range of estimates for the minimum operating level, and vice-versa. 
Table 9

Beginning-of-Month Stocks of All Oils

(Millions of Barrels)*

$\begin{array}{lrrr} & \underline{1977} & \underline{1978} & \underline{1979} \\ \text { January } & 1,112 & 1,304 & 1,215 \\ \text { February } & 1,065 & 1,258 & 1,154 \\ \text { March } & 1,050 & 1,177 & 1,072 \\ \text { April } & 1,087 & 1,150 & 1,063 \\ \text { May } & 1,121 & 1,152 & 1,086 \\ \text { June } & 1,171 & 1,150 & 1,092 \\ \text { July } & 1,195 & 1,155 & 1,121 \\ \text { August } & 1,239 & 1,187 & 1,166\end{array}$

* Not including Strategic Petroleum Reserve.

Table 10

Stock Levels and Percent Change In Available Stocks of All Oils Between 1978 and 1979

(Millions of Barrels)

$\begin{array}{lcc} & \text { January 1 } & \text { April 1 } \\ 1978 \text { Level } & 1,304 & 1,150 \\ 1979 \text { Level } & 1,215 & 1,063 \\ \text { Minimum Level } & 950-1,030 & 950-1,030 \\ 1978 \text { Available for Drawdown } & 274-354 & 120-200 \\ 1979 \text { Available for Drawdown } & 185-265 & 33-113 \\ \text { Percent Change } & 25-33 \% \text {. } & 44-72 \%\end{array}$


D. Gasoline Stocks

Table 11 shows gasoline stock levels at the beginning of the month from January through August of 1977, 1978 and 1979.

Using the same method described in Section $C$, the difference between the amount of gasoline stocks available for supply in 1979 relative to 1978 can be calculated for January 1 and April 1. Respectively, the 1979 decreases were $34-42 \%$ and $35-42 \%$, where the lower end of the range reflects the lower estimate of minimum operating level, and vice versa. Figure 6 shows a graph of these stock levels.

Table 11

Gasoline Stocks at the Beginning of the Month

(Millions of Barrels)

$\begin{array}{llll} & \underline{1977} & \underline{1978} & \underline{1979} \\ \text { January } & 231 & 258 & 238 \\ \text { February } & 253 & 272 & 256 \\ \text { March } & 256 & 271 & 251 \\ \text { April } & 262 & 260 & 239 \\ \text { May, } & 259 & 249 & 235 \\ \text { June } & 263 & 234 & 227 \\ \text { July } & 256 & 219 & 229 \\ \text { August } & 258 & 216 & 242\end{array}$


Figure 6. Gasoline Stocks at the Primary Level, January-August, 1977, 1978, 1979

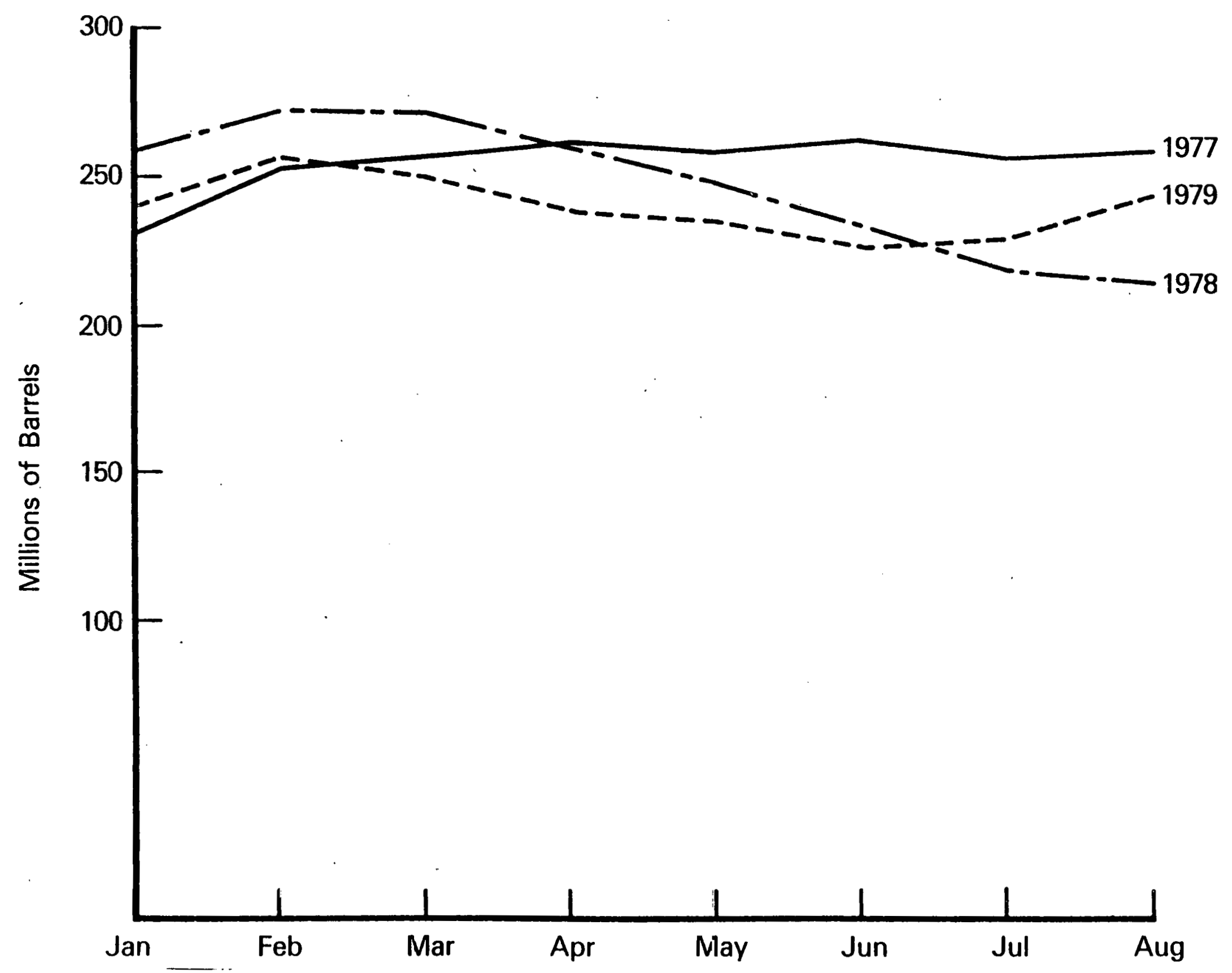


E. Product Yields

Table 12 shows average U.S. refinery yields of various petroleum products for the May-July period in 1977, 1978 and 1979. The gasoline yield in 1979 was 1.2 percentage points less than in 1978 , and 1.0 percentage point less than in 1977. Had the average of the 1977 and 1978 yields been maintained in 1979, gasoline production would have been $174 \mathrm{mb} / \mathrm{d}$ greater, and petrochemical feedstocks 157 less.

The yield analysis was also performed excluding natural gas liquids and other hydrocarbon inputs which are passed through the refinery entirely into gasoline production. This analysis shows the yield of products based only on crude oil input. The conclusion is that had the average fractions for 1977 and 1978 been maintained in 1979, gasoline production would have been $192 \mathrm{mb} / \mathrm{d}$ greater and petrochemical feedstock production $170 \mathrm{mb} / \mathrm{d}$ less.

Table 12

May-July Refinery Production and Yield Fractions for Various Products (Thousands of Barrels Per Day)

1977

1978

1979

Production Fraction* Production Fraction* Production Fraction*

Motor Gasoline

Aviation Fuels

Petrochemicals

$7,110 \quad .447$

$1,030 \quad .065$

$610 \quad .039$

Kerosene

150

.009

Middle Distillates

3,170

.200

Residual Fuel Oil

$1,710 \quad .108$

Other

$\underline{2,120} \quad .133$

7,180

.449

1,010

730

6,930

1,000

840

$130 \quad .008$

.046

$3,160 \quad .198$

160

3,170

1,600

.100

1,570

, $\underline{2,180}$

.437

$\underline{2,180} \quad .136$

15,850

TOTAL

15,900

15,990

200

.098

.137

* The numerator is the production of the particular product. The denominator is the production of all products. 


\section{F. Gasoline Prices}

As shown in Table 13, gasoline prices rose by 29.8 cents per gallon between January and August of 1979. Increases in crude oil costs accounted for 18.5 cents ( $62 \%$ of the total). $21 /$ Another 5.7 cents (19\%) was added to the retail margin and 3.7 cents ( $12 \%$ ) was added to the margins of refiners and resellers combined (the data do not allow separation of refiner and reseller margins). These margin increases include a number of cost increases which cannot be explicity separated out using available data. Except to the extent that DOE's gasoline price controls may have been violated, all of these margin increases were justified by cost increases, although at the retail level a substantial portion of the increase was costs which had been incurred prior to January 1979 and banked rather than passed through in the month in which they occurred.

21/ In calculating the crude costs of gasoline, the refiner acquisition cost of crude oil was increased by $10 \%$. This is because the market for heavier products will not bear a proportional share of crude oil costs. Since gasoline cannot be produced without producing heavier products at the same time, gasoline must bear some of the crude oil cost of the heavier products. The actual degree of cost reallocation cannot be precisely calculated, but DOE has determined that $10 \%$ is a reasonable estimate on the basis of the record compiled during the gasoline tilt rulemaking. 
Table 13

Components of Leaded Regular Gasoline Price Increases

(Cents Per Gallon)

\begin{tabular}{|c|c|c|c|c|}
\hline & January & September & Change & $\begin{array}{l}\text { Change in } \\
\text { Component as a } \\
\text { Percentage of Retail } \\
\text { Price Increase }\end{array}$ \\
\hline Retail Price & 68.4 & 98.2 & +29.8 & $100.0 \%$ \\
\hline Retail Tax & 13.1 & 13.8 & +0.7 & $2.3 \%$ \\
\hline Retail Margin & 8.3 & 14.0 & +5.7 & $19.1 \%$ \\
\hline $\begin{array}{l}\text { Refiners' Crude } \\
\text { Costs* }\end{array}$ & 31.3 & 52.8 & 178.5 & $62.1 \frac{?}{0}$ \\
\hline $\begin{array}{l}\text { Refiner's Energy } \\
\text { Costs** }\end{array}$ & 2.2 & 3.4 & +1.2 & $4.0 \%$ \\
\hline Margin*** & 10.5 & 14.2 & +3.7 & $12.4 \%$ \\
\hline
\end{tabular}

* Based on $110 \%$ of actual crude costs to reflect tilt.

** Calculated as $7 \%$ of crude oil cost to reflect $7 \%$ energy penally in refining gasoline.

*** Includes labor, overhead, transportation, purchased gasoline, passthrough of previously banked costs, and illegal overcharges, if any, for refiners and resellers. 


\author{
APPENDIX A: \\ Sources of Data Used in this Report
}

Figure 1 , page 18

All points plotted in the Figure are rolling 3-month averages.

- Net U.S. Imports: 1977-78: EIA Energy Data Reports, Petroleum Statement Annual, "Crude Petroleum, Petroleum Products, and Natural Gas Liquids" (referred to hereafter as the Annual Statement.) Net U.S. imports were derived from Table 1 of the Annual Statement, by adding the five categories of imports shown, and subtracting the two categories of exports shown. Since SPR imports are included in Table 1 of the Annual Statement, they were subtracted out for the purposes of preparing Figure 1. Monthly SPR import levels were taken from the table on page 30 of the November 1979 Monthly Energy Review.

1979: EIA Energy Data Reports, Petroleum Statement Monthly, "Crude Petroleum, Petroleum Products, and Natural Gas Liquids" (referred to hereafter as the Monthly Statement). Net U.S. imports were derived from Table 1 of the Monthly Statement and page 30 of the Monthly Energy Review in the same manner as described above. Revisions for January-November were published in Table 23 of the December monthly statement.

- U.S. Production:

1977-78: Derived from Table 1 of the Annual Statement, by adding the three categories of domestic production shown.

1979: Derived from Table 1 of the Monthly Statements, from the line showing "total products supplied for domestic use."

- U.S. Demand:

1977-78: Derived from Table 1 of the Annual Statement, from the line showing "total products supplied for domestic use."

1979: Derived from Table 1 of the Monthly Statements, from the line showing "total products supplied for domestic use."

- New Supply:

This is the sum of Net U.S. imports and U.S. production. 
Table 1, page 21

This table is derived entirely by addition and subtraction from Table.7, page 41 .

Table 2, page 22

This table is derived from Table 1, page 21, adjusted for closing stock levels as shown in the footnote to Table 2 . The closing stock level numbers are taken from the Annual Statement (1977 and 1978), and the Monthly Statements (1979), and reduced by the amount of oil in the Strategic Petroleum Reserve. The SPR totals are taken from the table on page 30 of the November 1979, Monthly Energy Review.

Table 3 , page 23

- Crude Oil: Domestic crude oil production and the split between lower-48 production and Alaskan production were taken from the Monthly Energy Review, November 1979, page 30 .

- Natural Gas Liquids: NGL production is taken from Table 1 of the Annual Statement (1977 and 1978) and the Monthly Statements (1979).

Figure 2, page 24

The data plotted in Figure 2 are monthly average production levels for the lower-48 states. The production levels are derived by subtracting Alaskan production from total domestic production of crude oil as shown in the table on page 30 of the November 1979 Monthly Energy Review.

The trend line shown in Figure 2 is the least-squares line fit to monthly production levels from January 1973 through August 1979. The regression equation contained only one independent variable (the number of months elapsed since December 1972). The correlation coefficient for this regression was .96 .

Figure 3, page 26

- Iranian Production: this is taken from the table on page 4 of the March, 1980 edition of International Energy Indicators published by DOE's Office of International Affairs.

- Production in the rest of the world: this is the sum of Saudi Arabian production shown on page 6 of International Energy Indicators, OPEC (Ex-Iran and Saudi Arabia) production shown on page 8, and Non-OPEC Free World and U.S. production shown on page 10 .

Figure 4 , page 28

- Total World New Supply: This was derived by adding U.S. production and non-U.S. production, lagged by one month. U.S. production was taken from Table 1 of the Annual Statement (1977 and 1978), and the Monthly Statement (1979). Non-U.S. production was obtained from the CIA Energy Branch. 
- Non-U.S. New Supply: This was derived by subtracting U.S. New Supply from Total World New Supply.

- U.S. New Supply: This was derived by adding U.S. production of crude oil and natural gas liquids to net U.S. imports. Both were taken from Table 1 of the Annual Statement (1977 and 1978), and the Monthly Statement (1979).

\section{Table 4, page 31}

- Gasoline Production: This was taken from Table 2 of the Annual Statement (1977 and 1978), and the Monthly Statement (1979) divided by 92 (the number of days in the May-July period). Only motor gasoline production is included.

- Net Imports: This is gasoline imports minus exports, as shown in Table 2 of the Annual Statement (1977 and 1978), and the Monthly Statements (1979), divided by 92 (the number of days in the May-July period).

- Use of Stocks: This is derived for each year by subtracting the July 31 gasoline stock level from the April 30 stock level and dividing by 92 (the number of days in the May-July period).

- April 30 and July 31 Stock Levels: The stock levels were taken from Table 2 of the Annual Statement (1977 and 1978) and the Monthly Statements (1979).

\section{Table 5, page 36}

This table is derived from Table 12, page 48. The Hypothetical yield fraction for each product for 1977-78 is the average of the actual yield fractions for 1977 and 1978 shown in Table 12. The hypothetical yield for each product is then the hypothetical yield fraction for that product multiplied by 15,845 $\mathrm{mmb} / \mathrm{d}$, the actual total output of products in May-July 1979.

Table 6, page 40

This table is derived from Table 13, page 50 of this report.

Table 7 , page 41

- Domestic Production of Crude Oil and Natual Gas Liquids: These data are taken from Table 1 of the Annual Statement (1977 and 1978), and the Monthly Statements (1979).

- Net Imports of Crude, Feedstocks, and Products: These data are derived from Table 1 of the Annual Statement (1977 and 1978), and the Monthly Statements (1979), by subtracting exports from imports, and also subtracting out imports for the Strategic Petroleum Reserve. The SPR import levels are taken from page 30 of the November 1979 Monthly Energy Review. 
- Use of Crude, Feedstock and Product Stocks: This is determined by subtracting the closing stock level from the opening stock level (e.g., July 31 and April 30 for the May-July period), and dividing by the number of days in the period (e.g., 92 for the May-July period). Opening and closing stock levels are taken from the Annual Statement (1977 and 1978) and the Monthly Statement (1979), and adjusted by subtracting the amount of oil held in the Strategic Petroleum Reserve at the, end of the relevant period. The amount of oil in the SPR is taken from page 30 of the November Monthly Energy Review.

Figure 5, page 42

This figure is derived from the table on page 14 of the DOE publication, "International Energy Indicators," February 1980. (The original source of the data is the CIA Energy Branch.) The individual monthly consumption levels for the U.S. and the rest of the IEA plus France were transformed into the 3-month average for that month and the two preceding months, and this 3-month average for each month in 1979 was compared with the 3-month average for the same month in 1978. The percent change is plotted in Figure 5.

Table 8 , page 43

Production, net import, stock change data in this table are taken from Table 2 of the Annual Statement (1977 and 1978), and the Monthly Statements (1979).

Table 9 , page 45

The data in this table are derived from Table 1 of the Annual Statement (1977 and 1978) and the Monthly Statements (1979). Stocks held in the SPR are subtracted out. The SPR stocks are taken from page 30 of the November 1979 Monthly Energy Review.

Table 10 , page 45

The data in this table are derived from the data in Table 9, page 45 .

Table 11 , page 46

Stocks of gasoline were taken from Table 2 of the Annual Statement (1977 and 1978), and the Monthly Statements (1979).

Figure 6 , page 47

The data from Table 11 are used in the graph.

Table 12, page 48

The data in this table are derived from Table 16 of the Annual Statement ( 1977 and 1978), and Table 9 of the Monthly Statements (1979). "Aviation fuels" include aviation gasoline and jet fuels. "Petrochemicals" include liquid refinery gas for chemical use, and petrochemical feedstocks. 


\section{Table 13 , page 50}

- Retail Price: Taken from the table on page 83 of the February 1980 Monthly Energy Review (leaded regular full serve.)

- Retail Tax: DOE estimate.

- Retail Margin: This is derived by subtracting the retail tax and the refiners' average dealer tankwagon price from the retail price. The dealer tankwagon price is published in DOE's "Monthly Petroleum Product Price Report."

- Refiners' Crude Oil Cost: This is derived from the table on Page 83 of the February 1980 Monthly Energy Review. The dollar per barrel figures are divided by 42 to give dollars per gallon.

- Energy Costs: This is estimated by DOE based on crude oil costs and an estimate of the energy required to refine gasoline.

- Margin: This is the residual from the other components of the retail price. 


\section{APPENDIX B:}

Comparison of Final Data with Preliminary Data Presented in the July 24, 1979 Report

The tables that follow compare data contained in the July 24, 1979, report with final data for the same period. Table B-1 shows this comparison for the data shown on pages $10-11$ of the July 24 report. Table B-2 shows the comparison for data presented on page 15 of the July 24 report. Table B-3 shows the comparison for data presented on pages 10 and 17 of the July 24 report. Table B-4 shows the comparison for data presented on pages 30 and 31 of the July 24 report.

- The Preliminary Report concluded that imports during February-May averaged $800 \mathrm{mb} / \mathrm{d}$ less than needed to meet 1978 levels of demand. The final data indicate that the correct figure is $280 \mathrm{mb} / \mathrm{d}$. The difference is attributable to revisions in data, especially the level of product stocks at the beginning and end of the period. These revisions showed that approximately $400 \mathrm{mb} / \mathrm{d}$ more product stock drawdown occurred during the period than had been indicated by the preliminary data.

- The Preliminary Report concluded that the U.S. received $200 \mathrm{mb} / \mathrm{d}$ less than it would have if it had received the same percentage of IEA imports during the first half of 1979 as in 1978. Revised data indicate that the U.S. received approximately the same share of IEA 
imports in the first half of 1979 as in 1978, although the U.S.

received a significantly smaller share of total IEA supply. $\underline{22 /}$

- The Preliminary Report found that domestic crude oil production in February-May was $200 \mathrm{mb} / \mathrm{d}$ below the same period of 1978 . Revised data indicate that the actual reduction was $140 \mathrm{mb} / \mathrm{d}$.

22/ The U.S. share of IEA production declined between the first half of 1978 and the same period of 1979. Since the U.S. share of IEA imports held constant, this implies that the U.S. share of IEA supply dropped. See discussion on pages 27-30. 


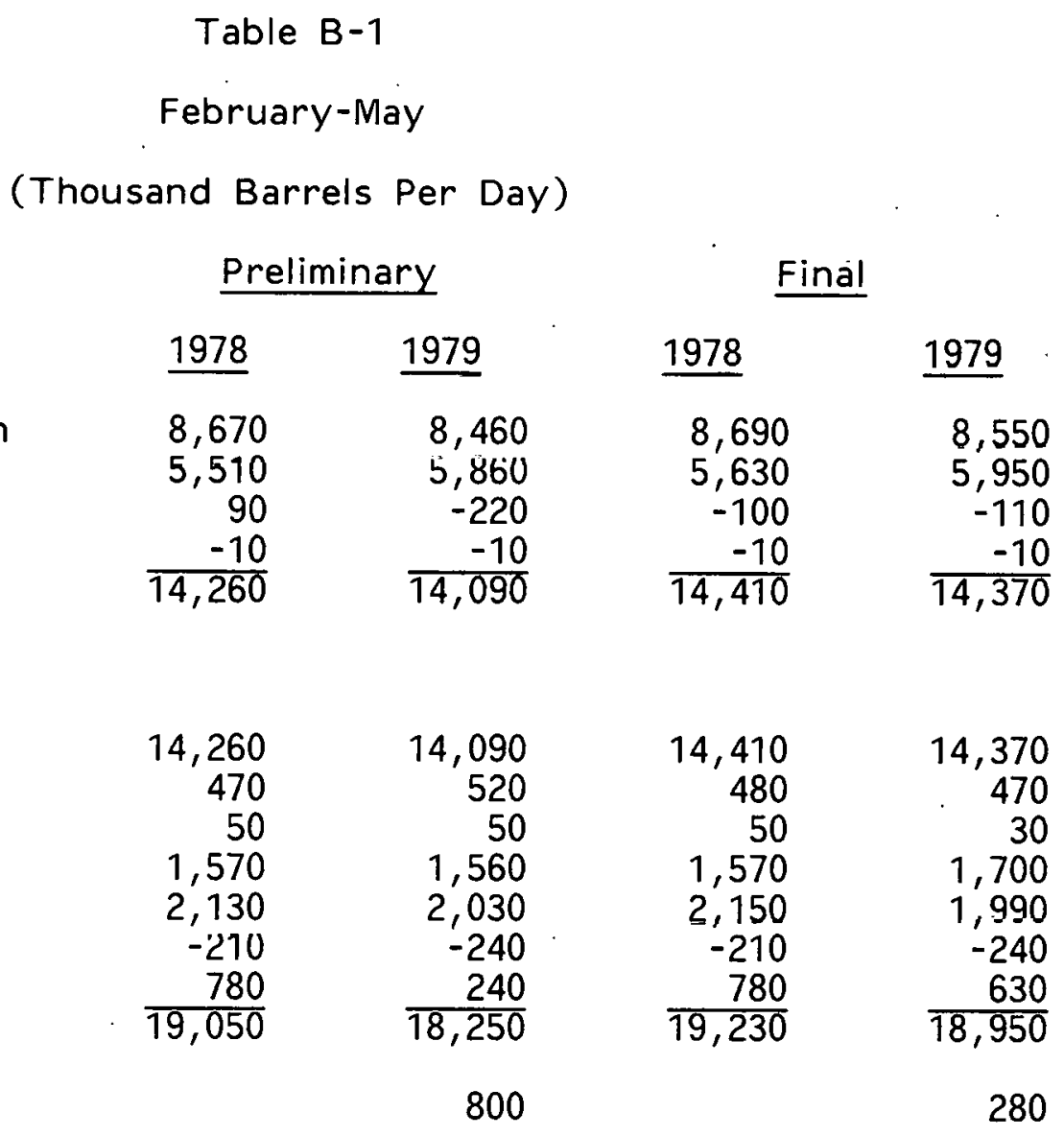

Table B-2

U.S. Received 200,000 B/D

Less Than They Would Have if They

Had Received Their Traditional Share

of IEA Imports

(Thousands of Barrels Per Day)

U.S. Imports IEA Imports U.S. Percent

Prelim Final Prelim Final Prelim Final

First Half 1978

$7,755 \quad 23,340 \quad 36.4 \% \quad 33.2 \%$

First Half 1979

Level
s
U.S
Less Than Rece
(Thousan

$\begin{array}{llllll}8,142 & 7,887 & 23,000 & 23,825 & 35.4 \% & 33.1 \%\end{array}$ 